\title{
The Czar and the Slaves: Two Puzzles in the History of INTERNATIONAL ARBITRATION
}

\author{
By Bennett Ostdiek* and John Fabian Witt
}

\section{ABSTRACT}

In 1822, the Russian czar resolved a dispute over compensation for slaves fleeing to British lines during the War of 1812. American observers have long asserted that this canonical decision favored the United States. But new debate has recently arisen among historians. Uncovering evidence from diplomatic archives, this Article concludes that the czar did indeed side with the United States. Moreover, the case demonstrates how nineteenth-century American statesmen pressed international law into service in support of slavery.

\section{INTRODUCTION}

On April 22, 1822, the Russian Czar Alexander issued a decision that has gone down in the annals as one of the canonical international arbitrations of the early American republic. Four years earlier, the United States and the United Kingdom had come to an impasse in a bitter debate over compensation owed to the United States for some or all of the 5,000 slaves who evacuated with the British after the War of 1812. At President James Monroe's suggestion, the United States had proposed to submit the question to the Russian emperor. Now at last the czar had delivered a decision, one that seemed to be in the United States' favor. But was it? Secretary of State John Quincy Adams complained at the time that the decision was not sufficiently clear. New debate among historians has put the issue of who won the czar's arbitration in question.

* J.D. candidate, Yale Law School.

** Allen H. Duffy Class of 1960 Professor of Law, Professor of History, and Head of Davenport College, Yale University.

The authors thank Ryan Brasseaux, Jay Gitlin, Oona Hathaway, Alieta-Marie Lynch, Jim Oakes, Michael Reisman, and Anthea Roberts for helpful exchanges about the project. Lauren Miller, Elizabeth McKee, and Jordan Kindler offered invaluable research assistance, which the generosity of The Oscar M. Reubhausen Fund helped us secure. 
The traditional view holds that the czar's decision favored the United States. ${ }^{1}$ Modern historians have repeated the claim. ${ }^{2}$ But the outcome was not quite as clear as it has sometimes seemed.

Leading international arbitration scholar John Bassett Moore sensed the ambiguity 120 years ago when he assessed the situation with more caution than most other observers. "[I]t appears," Moore wrote, choosing his words carefully, "that the point of difference was decided in favor of the United States." 3 Distinguished historian James Oakes has recently gone much further, arguing not only that the resolution was unclear, but insisting that the czar decisively sided with the British. As Oakes tells the story: "On July 12, 1822, Czar Alexander I issued his decision, resoundingly endorsing the British reading of the treaty." Oakes explains that, under the award, "[t]he United States was entitled to 'a just indemnification' only for those slaves 'carried away from places and territories of which the Treaty stipulates the restitution." However, he points out that the czar ruled that the United States was "not entitled to claim an indemnification" for "the thousands of slaves carried away from areas 'not stipulated' for restitution." Oakes argues that "[ $t]$ his had been the British position all along - the prohibition on the removal of private property, including slaves, applied only to slaves physically located in those places specifically slated for restitution in the treaty." Thus, the British justifiably "read the czar's decision as a vindication." 4

What, then, is the answer? Who won the arbitration in St. Petersburg is the first puzzle of the czar's arbitration. And it is a puzzle that we answer once and for all, relying on diplomatic archives and published diplomatic papers in the United States, the United Kingdom, and Russia to demonstrate that the czar sided with the slavers of the United States. We aim to shed light, too, on the closely related question of why the parties - and in particular the United Kingdom, which was far and away the stronger state after the War of 1812-were willing to arbitrate the slavery question in the first place. After all, the UK's navy dominated the seas. Its armies had recently put the United States' capital to the torch. Settling claims

\footnotetext{
${ }^{1}$ William Renwick Riddell, Settlement of International Disputes by and Between the English Speaking Nations, 22 YALE L.J. 545, 547-48 (1913) ("The Emperor of Russia . . . made his award, holding Britain liable for these slaves."); Arnett G. Lindsay, Diplomatic Relations Between the United States and Great Britain Bearing on the Return of Negro Slaves, 1783-1828, 5 J. Negro Hist. 391, 414-15 (1920) ("The point of difference was decided in favor of the United States. .. . [T] he Emperor held that the limitations as to the restitution of public property bore no relation to private property.”); SAMUel FlagG Bemis, John Quincy AdAms AND THe Foundations of American Foreign Policy 293 (1949) (under "the Czar's opinion . . . the United States was entitled to indemnity”); Bradford Perkins, Castlereagh and Adams: England and the United States, 1812-1823, 166 (1964) ("Russia decided in favor of the Americans.").

${ }^{2}$ Don E. Fehrenbacher, The Slaveholding Republic: An Account of the United States Government's Relations to Slavery 95 (Ward McAfee ed., 2001) ("The imperial decision . . . declared that the 'literal and grammatical sense' of the treaty supported the American claim and that the United States was therefore entitled to a 'just indemnification' for the slaves carried away.”); MAYA JASANOFF, LiBERTY's EXILES: AMERICAN LOYALISTS IN THE AGE of Revolution 330 (2011) ("When the United States lodged a compensation claim for evacuated slaves, Britain . . . agreed to pay American slaveholders . . ..”); Henry J. Richardson III, The Origins of AfricANAmerican Interests in International LaW 438 (2008) ("The Emperor of Russia . . handed down his award in favor of the United States.”); Alan Taylor, The InTernal Enemy: SlaVery and War in Virginia, 1772-1832, 431 (2013) (asserting that "the czar understood the American idiom better than the British," for he "rul[ed] for the republic and against the empire"); John Fabian Witt, Lincoln's Code: The Laws of War in American History 76 (2012) ("The czar . . . ruled that the American construction of the treaty was the sound one.").

31 John Bassett Moore, History and Digest of the International Arbitrations to Which the United States Has Been a Party 363 (William S. Hein \& Co., 1995) (1898).

${ }^{4}$ James Oakes, The Scorpion's Sting: Antislavery and the Coming of the Civil War 141-42 (2014).
} 
about slaves carried off in the War of 1812, moreover, was deeply unpopular with nationalist and antislavery constituencies at home in Britain. Under these circumstances, arbitration offered the UK an opportunity to settle the slave dispute at a time when other questions had come to seem more pressing to British officials. An ostensibly neutral third-party arbiter offered a face-saving way out of an important diplomatic impasse and allowed both sides to come away with important gains — the United Kingdom included — even after the official victory went to the slaveholders of the United States.

The first puzzle of the St. Petersburg arbitration gives rise to a second. In the past decade, a fast-growing scholarly literature has brought renewed attention to the relationships between international law and slavery in precisely the years in which the United States and the United Kingdom brought their dispute over slaves before the czar. Thanks to the work of Lauren Benton, Lisa Ford, Jenny Martinez, and others, the history of international law has taken up the ways in which international law, bilateral treaties, and admirality courts helped bring an end to the legal slave trade in the Atlantic world: first by unilateral British action under the laws of war at sea during the Napoleonic conflicts; and then through a network of bilateral treaties after the Congress of Vienna. ${ }^{5}$ Some, like Martinez, contend that international law represented the first historical embodiment of the modern international human rights movement. ${ }^{6}$ Others, like Benton and Ford, argue that using international law to oppose the slave trade served the interests of an expanding British Empire. ${ }^{7}$ Either way, the czar's arbitration reveals that nineteenth-century international law was deeply implicated in slavery, too. In particular, the United States arrived on the scene as the leading advocate of a version of international law that aimed to bolster and defend slavery in the Atlantic world. The czar's pro-slaveholder decision in 1822 showed that American statesmen's pro-slavery vision of international law would be a plausible competitor to the anti-slave-trade rival emerging in the British Empire. ${ }^{8}$

\footnotetext{
${ }^{5}$ Lauren Benton \& Lisa Ford, A Rage for Order: The British Empire and the Origins of International Law, 1800-1850 (2016); Jenny S. Martinez, The Slave Trade and the Origins of International Human Rights Law (2012) [hereinafter Martinez, Slave Trade]; Manisha Sinha, The Slave's Cause: A History of Abolition 3-4 (2016); David Murray, Odious Commerce: Britain, Spain and the Abolition of the Cuban Slave Trade (1980); Philip Alston, Does the Past Matter? On the Origins of Human Rights: The Slave Trade and the Origins of International Human Rights Law, 126 Harv. L. Rev. 2043 (2013); Leslie Bethell, The Mixed Commissions for the Suppression of the Transatlantic Slave Trade in the Nineteenth Century, 7 J. African HIST. 79, 82 (1966); Lauren Benton, Abolition and Imperial Law, 1790-1820, 39 J. ImPerial \& COMMONWEALTH Hist. 355 (2011); Laurence R. Helfer \& Ingrid B. Wuerth, Customary International Law: An Instrument Choice Perspective, 37 Mich. J. InT'L Law 563, 587-89 (2016); Rebecca J. Scott, International Law and Contemporary Slavery: The Long View, 38 Mich. J. InT'L LaW 349, 350 (2017); Tara Helfman, Note, The Court of Vice Admiralty at Sierra Leone and the Abolition of the West African Slave Trade, 115 YALE L.J. 1122 (2006).

${ }^{6}$ Jenny Martinez, Human Rights and History, 126 Harv. L. REv. F. 221 (2012).

${ }^{7}$ E.g., Lauren Benton, This Melancholy Labyrinth: The Trial of Arthur Hodge and the Boundaries of Imperial Law, 64 AlA. L. Rev. 91 (2012) [hereinafter Benton, This Melancholy Labyrinth]; Edward Keene, A Case Study of the Construction of International Hierarchy: British Treaty-Making Against the Slave Trade in the Early Nineteenth Century, 61 Int'l Org. 311 (2007). See also Samuel Moyn, Substance, Scale, and Salience: The Recent Historiography of Human Rights, 8 Ann. Rev. L. \& Social Sci. 123 (2012); Samuel Moyn, Of Deserts and Promised Lands: The Dream of Global Justice, NATION (Feb. 29, 2012).

${ }^{8}$ On some of the ways in which international legal institutions bolstered slavery, see DAVID BRION DAVIS, THE Problem of Slavery in Western Culture (1966); John Thomas Noonan, The Antelope: The Ordeal of the Recaptured Africans in the Administrations of James Monroe and John Quincy Adams (1977); John Fabian Witt, Lincoln's Code: The Laws of War In American History (2012); Michael Byers, Policing the High Seas: The Proliferation Security Initiative, 98 AJIL 526, 534-36 (2004) (observing among other things that "the United States proved to be the major obstacle to the British effort to establish a generally applicable, nontreaty right of
} 
Part I of this Article describes the slave controversy at the end of the War of 1812, the drafting of the awkward provision in the 1814 Treaty of Ghent that purported to settle it, and the near-immediate dispute about the interpretation of that provision. Part II explains the czar's ruling and uses unpublished documentary evidence to show that the dispute's dénouement only makes sense if both parties to the dispute understood the czar to have affirmed the Americans' pro-slavery arbitration claims. We further describe the domestic political pressures that pushed the parties to arbitrate and observe that in several subtle respects, the United Kingdom gained from the arbitration, too, as did at least some of the black refugees who had found their way to British lines. In conclusion, we observe that the czar's arbitration surfaced pro-slavery dimensions of international law that the United States took a lead role in advocating. Viewed as a whole, international legal institutions were neither always subversive of slavery nor always supportive of it. Instead, international law had become a site of contestation over the great moral question of the age.

\section{From the Chesapeake to the Neva}

\section{A. A Crisis the Runaways Made}

In August 1814, with the War of 1812 drawing to a close, commissioners representing the United States and Great Britain met in the city of Ghent, Belgium, to negotiate the terms of a peace. The commission would consider many contentious issues over the coming months, including the disputed title to the Passamaquoddy Islands, the right of Americans to fish in British waters, and the right of British subjects to navigate the Mississippi River. ${ }^{9}$ No question ultimately proved more significant, however, than that of what to do with runaway slaves.

During the war, thousands of runaway American slaves had sought refuge behind British lines in the hope of securing their freedom. In April 1813, "British forces under the command of Rear Admiral George Cockburn began raiding American towns" located on the coast of the Chesapeake and Delaware Bays, and though Cockburn's official orders warned him to avoid fomenting slave rebellion, the admiral and his men instead quietly encouraged American slaves to join the British forces and serve as guides. ${ }^{10}$ Then on April 2, 1814, Vice Admiral Sir Alexander Cochrane, commander of British forces in North America, issued a proclamation declaring that "all those who may be disposed to emigrate from the United

visitation with respect to the slave trade"); Holger Lutz Kern, Strategies of Legal Change: Great Britain, International Law, and the Abolition of the Transatlantic Slave Trade. Strategies of Legal Change, 6 J. HisT. INT'L L. 233, 258 (2004) ("British legal concepts and ideas regarding the illegality of the slave trade did not simply prevail over traditional conceptions of international law."); Eugene Kontorovich, The Constitutionality of International Courts: The Forgotten Precedent of Slave Trade Tribunals, 158 U. Penn. L. Rev. 39, 62 (2009); Randy J. Sparks, Blind Justice: The United States's Failure to Curb the Illegal Slave Trade, 35 Law \& HIsT. REv. 53, 72 (2017); John Fabian Witt, A Social History of International Law: Historical Commentary 1861-1900, in INTERNATIONAL LAW IN the U.S. Supreme CourT 170-71 (David L. Sloss, Michael D. Ramsey \& William S. Dodge eds., 2011); Note, International Norms and Politics in the Marshall Court's Slave Trade Cases, 128 Harv. L. Rev. 1184 (2015).

9 The American Plenipotentiaries to the Secretary of State (Dec. 25, 1814), in 3 American State Papers: Foreign Relations 732, 732-33 (William S. Hein \& Co., 1998) (1832); Jon Latimer, 1812: War With America 391-92 (2007); Fred L. Engelman, The Peace of Christmas Eve 132-36 (1962); Perkins, supra note 1 , at $70-127$.

${ }^{10}$ WiTT, supra note 2, at 73; Frank A. Cassell, Slaves of the Chesapeake Bay Area and the War of 1812, 57 J. Negro Hist. 144, 144-49 (1972); Christopher T. George, Mirage of Freedom: African Americans in the War of 1812, 91 MD. Hist. MaG. 427, 431-34 (1996). 
States will, with their families, be received on board his Majesty's ships or vessels of war, or at the military posts that may be established upon or near the coast of the United States." 11 Cochrane further explained that any such emigrants would "have their choice of either entering into his majesty's sea or land forces, or of being sent as Free settlers to the British possessions in North America or the West Indies." 12 British forces widely distributed Cochrane's proclamation, and though it did not refer to slaves by name, its message was clear: the British were offering freedom to any enslaved person who could successfully cross their lines. ${ }^{13}$

The British had enacted a similar policy during the Revolutionary War. On November 7 , 1775, John Murray, the Earl of Dunmore and royal governor of Virginia, issued a proclamation granting freedom to "all indentured Servants, Negroes, or others" belonging to rebellious colonists who were "able and willing to bear Arms, they joining His Majesty's troops." 14 Four years later, in 1779, the commander of British armies in North America, General Henry Clinton, expanded Dunmore's proclamation, offering freedom to rebel-owned slaves from any colony who came behind British lines, regardless of if they served in the British army or not. All told, some 20,000 slaves escaped to the British over the course of the war. ${ }^{15}$

American slaves in the War of 1812 once again seized the opportunity that wartime presented them to claim their freedom. Military-aged men fled to the British in the greatest numbersindeed, Admiral Cochrane ultimately formed a Colonial Corps of Royal Marines composed of 200 escaped slaves - but numerous enslaved women and children also escaped to freedom, both alongside their husbands and fathers and on their own. ${ }^{16}$ By the end of 1814 an estimated 3,000 to 5,000 slaves from Virginia and Maryland alone had escaped from their American owners and found freedom behind British lines. They would never return to their owners again. ${ }^{17}$

The frequency with which slaves ran away from their masters during the war testifies to the fierceness with which enslaved peoples resisted the antebellum South's chattel labor system. As historian Frank A. Cassell pointed out in the Journal of Negro History in 1972, "The behavior of large numbers of Chesapeake slaves during 1813 and $1814 \ldots$ seems to support the idea that many slaves did not passively accept the system, that they harbored a profound desire for freedom, and that given an opportunity they could be very 'troublesome property."' 18 Indeed, " $\mathrm{t}$ ] he blacks who joined the British army to fight their former masters . . . demonstrated their profound alienation from and antagonism towards a country and a society that professed equality for all while tolerating bondage for some."19

This ability of slaves to run to British lines and thereby secure their freedom produced tremendous anxiety in the white planter class. As Cassell explains, though runaway slaves furthered the British war effort in many respects, " $[\mathrm{t}]$ he greatest advantage" that they provided

${ }^{11}$ MOORE, supra note 3, at 350.

${ }^{12} \mathrm{Id}$. at $350-51$.

${ }^{13}$ Id. at 351; WITT, supra note 2, at 74.

${ }^{14}$ Proclamation of Earl of Dunmore (Nov. 7, 1775), available at http://www.nationalarchives.gov.uk/ pathways/blackhistory/work_community/docs/dunmore_proclamation.htm.

${ }^{15}$ OAKes, supra note 4, at 105-06; WITT, supra note 2, at 29; Cassandra Pybus, Jefferson's Faulty Math: The Question of Slave Defections in the American Revolution, 62 WM. \& MARY Q. 243, 248-61 (2005).

${ }^{16}$ OAKES, supra note 4, at 132; WITT, supra note 2, at 74; LATIMER, supra note 9, at 249; Cassell, supra note 10, at 150-51.

${ }^{17}$ WITT, supra note 2, at 73-74; Cassell, supra note 10, at 154.

${ }^{18}$ Cassell, supra note 10, at 144; see also TAYLOR, INTERNAL ENEMY, supra note 2.

${ }^{19}$ Cassell, supra note 10 , at 154-55. 
"to the British ... was the white southerner's fear of the slaves." 20 Southern newspapers, in an attempt to suppress black flight, spread false rumors that the British were reselling escaped American slaves in the West Indies. Privately, elite white Southerners expressed their fears. They were concerned about more than just the lost value of the runaway slaves; with the memory of the Haitian slave rebellion of the 1790s near to mind, they worried that the war would lead to a slave insurrection. Washington socialite Margaret Bayard Smith told her sister that she worried more about "the enemy at home" than the British, while General John P. Hungerford expressed his fear that the "ruffian system" of British warfare would "light up one universal conflagration throughout these counties." 21 The actions of the planter class echoed their words. In Virginia, for example, the number of slaves either executed or deported for insubordination more than doubled between 1812 and 1814 , and the state's House of Delegates wrote to President James Madison requesting federal assistance in their struggle against their "internal enemies." 22

The war ended without the feared slave insurrection coming to pass. Nonetheless, the American commissioners arrived at Ghent prepared to represent the interests of these aggrieved Southern planters. Though a few thousand of their former slaves had found freedom in Canada, England, and the British Caribbean by the time the war came to an end, several thousand more remained in American territory, either behind British lines or on British ships docked on American waters. ${ }^{23}$ In addition to questions relating to fisheries, borders, and navigation rights, at the peace conference the Americans would be negotiating with the British over the future of these blacks - would they be allowed to keep the freedom that they had won with their feet, or would they be forced back into slavery?

\section{B. Seeds of a Treaty Dispute}

The American commission, led by John Quincy Adams, arrived in Ghent determined to force the British to return all escaped slaves still in American territory. As Adams later explained to then-Secretary of State James Monroe, "Our intentions were to provide that no slaves should be carried away. We had no thought of disguising or concealing those intentions." 24 Accordingly, the Americans initially proposed that the first article of the peace treaty contain the following language:

All territory, places, and possessions, without exception, taken by either party from the other during the war or which may be taken after the signing of this treaty, shall be restored without delay, and without causing any destruction or carrying away any artillery or other public property, or any slaves or other private property . . . 25

${ }^{20}$ Id. at 149; see also Donald Hickey, The War of 1812: A Forgotten Conflict 204 (bicentennial ed. 2012); Alan Taylor, The Civil War of 1812: American Citizens, British Subjects, Irish Rebels, \& Indian allies 112-13, 175 (2010); J. C. A. StagG, Mr. Madison's War: Politics, Diplomacy, and Warfare in the Early American Republic 395, 412, n. 487 (1983).

${ }^{21}$ George, supra note 10, at 437; WITT, supra note 2, at 73-74; TAYLOR, supra note 2, at 297.

${ }^{22}$ Cassell, supra note 10, at 150; George, supra note 10, at 436; WITT, supra note 2, at 74.

${ }^{23}$ OAKES, supra note 4, at 132; TAYLOR, supra note 2, at 335-42.

${ }^{24}$ Mr. Adams to Mr. Monroe (Sept. 5, 1815), in 4 American State Papers: Foreign Relations 117, 117 (William S. Hein \& Co., 1998) (1834).

${ }^{25}$ Copy of a Projet of a Treaty of Peace Submitted by the American to the British Plenipotentiaries at Ghent, on the 10th Day of November, 1814, and of the Alterations and Propositions Made by the Latter in the Margin of the 
In other words, when the British military left American territory, they would have to leave behind all runaway slaves.

John Quincy Adams made for an unlikely advocate for the interests of slaveholders. In the words of one biographer, "Taught by family, history and experience that freedom was every man's right, [Adams's] abomination of slavery was almost genetic." ${ }^{26}$ Indeed, while serving in the Senate in 1804 he had published a pseudonymous series of articles decrying "the infamous traffic of human flesh." 27 However, Adams was an ambitious man, and he knew that becoming a public champion of abolition would not help him politically. ${ }^{28}$ Thus, that same year he voted against a law that would have prohibited the importation of slaves into the Louisiana territory, declaring from the Senate floor, "Slavery in a moral sense is an evil, but as connected with commerce it has its uses. The regulations added to prevent slavery are insufficient. I shall therefore vote against them." 29

Moreover, Adams arrived in Ghent serving under a Southern secretary of state (Monroe) and a Southern president (James Madison). The influence of the slave power was abundantly evident in U.S. foreign policy; the antebellum United States operated under what historian Matthew Karp has recently termed "a foreign policy of slavery."30 Southerner slaveholders and their northern allies, Karp explains, "maintained a vise-like grip on the executive branch of the U.S. national government, including the presidency, the cabinet, and important lower levels of federal administration," and Karp argues that "[n] owhere did slaveholders wield their power with more energy or commitment than in the realm of foreign and military policy." 31 The late Donald Fehrenbacher made the point pithily: "At home, the American nation was a house divided by the slavery question, but in the conduct of foreign affairs it appeared consistently as a slaveholding republic." 32

The British government also had a complicated relationship with slavery. Anti-slavery had functioned as a powerful force within British politics since the late 1780s, and Parliament had abolished the slave trade in $1807 .{ }^{33}$ However, slavery itself remained legal in the British

Said Projet, Returned by Them to the American Plenipotentiaries, in 3 American State Papers: Foreign Relations, supra note 9, at 735, 735 [hereinafter Projet of a Treaty] (emphasis added); see also Moore, supra note 3 , at 353-54.

${ }^{26}$ Phyllis Lee Levin, The Remarkable Education of John Quincy Adams 61 (2015).

27 Publius Valerius No. V, in 3 Writings of John Quincy AdAms 69, 71 (Worthington Chauncey Ford ed., 1914); William J. Cooper, The Lost Founding Father: John Quincy Adams and the Transformation of AMERICAN POlitics 74 (2017).

$28 \mathrm{Id}$. at 176.

${ }^{29}$ BEMIS, supra note 1 , at 122.

${ }^{30}$ Matthew Karp, This Vast Southern Empire: Slaveholders at the Helm of American Foreign Policy 7 (2016).

31 Id. at 4-5.

${ }^{32}$ Fehrenbacher, supra note 2, at 91; see also Matthew Mason, Slavery and Politics in the Early American RePubliC 93 (2006) ("That John Quincy Adams should have been such a bulldog in haggling over compensation for lost human property illustrated the power of American slaveholders in shaping American policy."); Matthew Mason, The Battle of the Slaveholding Liberators: Great Britain, the United States, and Slavery in the Early Nineteenth Century, 59 WM. \& MARY Q. 665 (2002) [hereinafter Mason, Slaveholding Liberators]. Adams did ultimately become an outspoken opponent of slavery, aggressively attacking the institution in the 1830s and 1840s, after he had finished his term as president and entered the U.S. House of Representatives. CoOper, supra note 27, 333-42, 353-54, 373-75.

33 Seymour Drescher, Abolition: A History of Slavery and Antislavery 209-28 (2009); David Brion Davis, The Problem of Slavery in the Age of Revolution, 1770-1823, at 20-27 (1999). 
Empire, and contemporary observers estimated the imperial slave population at over one million in $1814 .{ }^{34}$ Indeed, Henry Goulbourn, one of the British negotiators at Ghent, owned more than 250 slaves that labored for his benefit on a Jamaican sugar plantation, and Admiral Cochrane, the British officer who had issued the proclamation offering freedom to fugitive slaves during the war, owned slaves in Trinidad. ${ }^{35}$ Goulbourn's and Cochrane's status as slaveowners helps us to better understand historian Matthew Mason's argument that, in the War of 1812, "Britain freed American slaves for a variety of reasons, of which abolitionist sentiment was at best a small one." 36 Rather, the country was primarily concerned with promoting its international reputation "as an honorable force for freedom." 37 The British, Mason explains, desired "to be seen as the champion of liberty on an Atlantic stage." 38

Many in Britain viewed "slavery as abhorrent." 39 However, as Christopher Brown argues in his landmark study of the roots of British abolitionism, "helping enslaved Africans often mattered far less to the opponents of slavery than more proximate and sometimes very different goals." ${ }^{0}$ For example, while "[s] upport for slavery could become an embarrassment if and when the virtue of imperial rule became a public question ..., moral capital might be accrued by framing antislavery initiatives as an emblem of the national character." 41 Thus, when Adams suggested (with no evidence) to Goulbourn early in the negotiating process that the British had sold runaway American slaves in the West Indies, Goulbourn made it clear that he "regarded this "charge as a gratuitous national insult," notwithstanding that he personally owned slaves in the West Indies. ${ }^{42}$ This reaction proves consistent with one historian's observation that "[a]bsentee planters in Great Britain, especially those who were active in public affairs, were highly vulnerable to antislavery propaganda and likely to support measures to ameliorating slavery." 43 We can generalize this insight to the British government as a whole. Loudly denouncing slavery in highly moralistic terms helped British officials ignore deep tensions between their preferred self-image as global liberators and the uncomfortable fact that they presided over a slave empire.

It should not prove surprising, then, that the British commissioners rejected the language proposed by the American negotiators. To abandon runaway slaves who had sought refuge behind their lines would make a mockery of Britain's claim to be a force for liberty.

${ }^{34}$ DresCHER, supra note 33 , at 205.

35 Brian Jenkins, Henry Goulbourn, 1784-1856: A Political Biography 49-55, 81-89 (1996); Mason, Slaveholding Liberators, supra note 32, at 676 n.46.

${ }^{36}$ Mason, Slaveholding Liberators, supra note 32, at 671.

37 Id. at 672.

${ }^{38}$ Id. at 667; see also Jeffrey Glover, Witnessing African War: Slavery, the Laws of War, and Anglo-American Abolitionism, 74 WM. \& MARY Q. 503 (2017).

39 Christopher leslie Brown, Moral Capital: Foundations of British Abolitionism 3 (2006).

${ }^{40} \mathrm{Id}$. at 25 .

${ }^{41}$ Id. at 27. See also Oded Löwenheim, "Do Ourselves Credit and Render a Lasting Service to Mankind": British Moral Prestige, Humanitarian Intervention, and the Barbary Pirates, 47 INT'L STUD. Q. 23, 23 (2003) (using the case of the British intervention in the Algerian slave trade to argue that "the pursuit or moral prestige and credibility should also be incorporated into our understanding of humanitarian intervention").

${ }^{42}$ Mason, Slaveholding Liberators, supra note 32, at 673-75; JenKINs, supra note 35, at 84-85; 3 JOHN QUINCY Adams, Memoirs of John Quincy Adams, Comprising Portions of His Diary from 1795 to 1848, at 26 (Charles Francis Adams ed., Philadelphia, J.B. Lippincott \& Co., 1874).

43 JeNKINS, supra note 35, at 95. 
Accordingly, the British commissioners suggested the following modification to the American proposal:

All territory, places, and possessions, without exception, belonging to either party, and taken by the other during the war or which may be taken after the signing of this treaty, shall be restored without delay and without causing any destruction or carrying away any artillery or other public property, or any slaves or other private property, originally captured in the said forts or places, and which shall remain therein upon the exchange of the ratifications of this treaty. ${ }^{44}$

In other words, the British proposed to return to the United States only those runaway slaves who, upon the treaty's ratification, remained in the fort or place where they had originally joined the British ranks. If accepted, this language would have limited the number of slaves that the British were required to return to the Americans to a handful at most, and perhaps zero-in any event, it would be a number small enough as apparently not to trouble either Britain's conscience or its reputation. ${ }^{45}$

The American commissioners balked at this offer. Instead, they proposed to transpose the limitation added by the British, placing it after the phrase "public property" rather than after the phrase "private property." 46 The British agreed, and after some back and forth over how to deal with a disputed chain of islands on the American-Canadian border, the two sides agreed on the following language:

All territory, places, and possessions whatsoever taken by either party from the other during the war, or which may be taken after the signing of this treaty, excepting only the islands hereinafter mentioned, shall be restored without delay, and without causing any destruction or carrying away any of the artillery or other public property originally captured in the said forts or places, and which shall remain therein upon the exchange of the ratifications of this treaty, or any slaves or other private property. ${ }^{47}$

With this language finalized, the British and American commissioners signed the treaty on December 24, 1814. The Senate ratified the treaty on February 16, 1815, and when Secretary of State Monroe exchanged ratifications with the British representative in Washington the next day, the war officially came to an end. ${ }^{48}$ The two sides do not appear to have discussed the significance of the transposition of the words "originally captured." 49 Adams later believed that the British simply had not given the question any real thought. "The plain truth, as I

${ }^{44}$ Projet of a Treaty, supra note 25, at 735 (emphasis added); see also Moore, supra note 3, at 354.

${ }^{45}$ OAKES, supra note 4, at 134; WITT, supra note 2, at 75-76; The Secretary of State [James Monroe] to Mr. Baker, Chargé d'Affaires of His Britannic Majesty (Apr. 1, 1815), in 4 American State Papers: Foreign RELATIONS, supra note 24, at 106, 107 [hereinafter Monroe to Baker].

${ }^{46}$ Protocol of a Conference Held the 1st of December, 1814, at Ghent, in 3 American State Papers: ForeigN Relations, supra note 9, at 742, 742; see also Moore, supra note 3, at 354.

${ }^{47}$ Treaty of Peace and Amity Between His Britannic Majesty and the United States of America (Dec. 24, 1814), in 3 American State Papers: Foreign Relations, supra note 9, at 745, 746 [hereinafter Treaty of Peace] (emphasis added).

${ }^{48}$ Id. at 748; HICKEY, supra note 20, at 300.

${ }^{49} \mathrm{Mr}$. Baker to Mr. Monroe (Apr. 3, 1815), in 4 American State Papers: Foreign Relations, supra note 24, at 107, 107 [hereinafter Mr. Baker to Mr. Monroe]. 
believe," he wrote, "is that the British Plenipotentiaries at Ghent and their Government agreed to it without reflecting upon what they promised by it." 50

And there lay the seeds of a treaty dispute. The American diplomats left Ghent convinced that they had successfully represented the interests of their country's aggrieved slaveholders. The British commissioners returned home satisfied that they had vindicated their nation's reputation as a champion of freedom. Both sides could not be right.

\section{Dueling Interpretations}

Disagreement as to the meaning of the treaty's language broke out less than a week after Senate ratification. On February 23, 1815, American officials wrote to Captain John Clavelle, commander of the British forces in the Chesapeake Bay, to inform him that "under the stipulations of the first article of the . . treaty, all slaves, and other private property, which may now be in possession of the forces of His Britannic Majesty within the Chesapeake, are claimed to be delivered up forthwith." ${ }^{1}$ Captain Clavelle replied that he interpreted the treaty differently:

I understand the first article of the treaty, relative to private and public property, thus, viz: all territory, places, and possessions whatsoever, taken from either party by the other during the war, or which may have been taken after the signing this treaty, excepting only the islands hereafter mentioned, shall be restored without delay, and without causing any destruction or carrying away any of the artillery or other public stores, or any slaves, or other private property originally captured in the said forts or places, and which shall remain therein upon the exchange of the ratification of this treaty.

Accordingly, Captain Clavelle rejected the Americans' demands, declaring that since "none of the slaves now in Tangier [an island in the Chesapeake] were captured there, I cannot feel myself at liberty to deliver them up." 52 Similarly, Admiral George Cockburn, commander of the British forces on Cumberland Island, Georgia, responded to an American demand that he turn over all runaway slaves in his possession by offering to return to the United States "whatever public or private property or slaves (originally captured here) remained upon the island at the date of the ratification." ${ }^{3}$ Cockburn refused even to discuss the return of slaves captured "elsewhere on land or water, and which have been removed from the places where captured prior to the exchange of the ratifications of the treaty." 54 In this manner, Admiral Cockburn and Captain Clavelle both made it clear that they read the clause "originally captured in the said forts or places, and which shall remain therein upon the exchange of the ratification of this treaty" to apply not only to public property, such as artillery, but also to private property, including slaves.

\footnotetext{
505 John Quincy Adams, Memoirs of John Quincy Adams, Comprising Portions of His Diary from 1795 TO 1848, at 160 (Charles Francis Adams ed., Philadelphia, J.B. Lippincott \& Co., 1875).

${ }^{51}$ Messrs. Bayly, Graham, and Skinner to Mr. Clavelle (Feb. 23, 1815), in 4 American State Papers: Foreign Relations, supra note 24, at 108, 108.

${ }^{52}$ Mr. Clavelle to Messrs. Bayly, Graham, and Skinner (Feb. 23, 1815), in 4 American State Papers: Foreign Relations, supra note 24, at 108, 108 [hereinafter Mr. Clavelle to Messrs. Bayly, Graham, and Skinner].

53 Admiral Cockburn to Messrs. Newell and Spalding (Mar. 7, 1815), in 4 American State PaPers: Foreign Relations, supra note 24, at 111, 111 [hereinafter Admiral Cockburn to Messrs. Newell and Spalding].

${ }^{54} \mathrm{Id}$. at 112
} 
Frustrated by the officers of the Royal Navy, American officials next tried their luck with British diplomats. Secretary of State Monroe wrote to Anthony St. John Baker, the British Chargé d'Affaires in Washington, D.C., to complain that "the commanders of His Britannic Majesty's naval forces . . . have construed the stipulation in the first article of the treaty of peace, lately concluded between the United States and Great Britain, very differently from what is thought to be a just construction of it by this Government." 55 Namely, Monroe explained, the British naval commanders "comprise slaves, and other private property, under the same regulation with . . public property, and [they] contend that none ought to be restored except such as were, at the time of the exchange of the ratifications of the treaty, in the forts and places where they were originally taken." ${ }^{56}$ However, Monroe argued, "[a] very obvious distinction exists between private and public property," and he insisted that "[t]he terms of the article preserve this distinction." ${ }^{57} \mathrm{He}$ continued:

Had it been intended to put slaves and other private property on the same ground with artillery and other public property, the terms "originally captured in the said forts or places, and which shall remain therein on the exchange of the ratifications of this treaty," would have followed at the end of the sentence after "slaves and other private property." In that case, both interests, the public and the private, would have been subject to the same restraint. But, by separating them from each other, and putting the restrictive words immediately after "artillery and other public property," it shows that it was intended to confine their operation to those objects only, excluding from it "slaves and other private property." 58

Monroe further argued that "the spirit and equity of the article" aligned with the American interpretation of the treaty. ${ }^{59}$ After all, "none of the slaves were taken in forts or other places where the British troops happened to be at the exchange of the ratifications of the treaty." 60 Since "this fact was well known to the commissioners of both nations, it furnishes a conclusive argument against the construction contended for by the British naval commanders. It cannot be believed that the commissioners would have agreed to a stipulation which they respectively knew would produce no effect." 61 Accordingly, Monroe urged Baker to instruct "the British naval commanders not to carry away any of the slaves and other private property which may thus be fairly claimed by the United States."62

Baker did no such thing. Instead, he countered both the textual and equitable arguments that Monroe had made. First, Baker pointed out that "it could not have been intended by the plenipotentiaries of the two countries that there should be a general prohibition against carrying away from the places restored all private property of every description, and to whomever belonging, found therein on the exchange of the ratifications." 63 Therefore, since "some

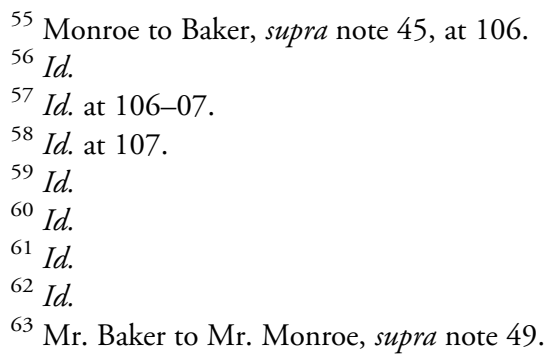


limitation must have been contemplated in the case of private as well as public property," the British commanders could have reasonably concluded that "the restriction attached by the words immediately preceding to the latter, was likewise applicable to the former." ${ }^{64}$ In other words, Baker argued that regardless of the text's plain meaning, the treaty's structure suggested that the limiting clause applied to both public and private property. Second, Baker declared that if the British commissioners at Ghent had thought that "the words were susceptible of the construction now given to them, and that a claim would be founded upon them for the delivering up of persons who had sought refuge during the war on board of British ships, their insertion would have been decidedly objected to, and others proposed." 65 Thus, the diplomat responded to Monroe's equitable point by suggesting that his country would have never agreed to a treaty that required them to return runaway slaves who had sought protection behind their lines.

Other British officials offered less legalistic defenses of their country's interpretation of the treaty. Instead, they spoke about the issue in openly moral terms. For example, Sir James Cockburn, the Governor of Bermuda (and older brother of Admiral Cockburn), declared to one American agent that "he would rather Bermuda, and every man, woman, and child in it, were sunk under the sea, than surrender one slave that had sought protection under the flag of England." 66 Similarly, Captain Clavelle asserted that he would not "give up those now serving on board His Britannic Majesty's ships," no matter what the treaty said. "[B]y entering into the service," Clavelle protested, the American slaves had made "themselves free men." 67

It is fair to say that neither side distinguished itself for its moral consistency. On the one side, American slaveholders claimed the mantle of fairness while defending property in persons through crabbed grammatical constructions. British diplomats and soldiers meanwhile made grand declarations about freedom even as the British empire remained home to over a million slaves.

\section{The Road to Arbitration}

With their efforts to convince the British military and diplomatic officials stationed stateside having proved unsuccessful, the United States decided to press the issue in London. On August 9, 1815, John Quincy Adams, now the American minister to the Court of St. James, wrote the British Foreign Minister, Lord Castlereagh, to request that the British government either "direct the restitution of the slaves conformably to the treaty, or ... provide for the payment of the value of those carried away contrary to that stipulation." In addition to reaffirming the textual arguments that Monroe had previously made to Baker, Adams suggested that the treaty's drafting history also supported the American construction. He explained that "a reference to the documents of the negotiation at Ghent may serve to elucidate the intentions of the contracting parties.”

\footnotetext{
${ }^{64} \mathrm{Id}$.

${ }^{65} \mathrm{Id}$.

66 Thomas Spandling, Esq. to the Secretary of State [Monroe] (May 1815), in 4 American State Papers: Foreign Relations, supra note 24, at 113, 113; TAYLOR, supra note 2, at 305, 343.

${ }^{67} \mathrm{Mr}$. Clavelle to Messrs. Bayly, Graham, and Skinner, supra note 52.
} 
The Americans had initially suggested language that unconditionally prohibited the removal of both public and private property; the British had countered by proposing to add the phrase "originally captured in said forts or places, and which shall remain therein upon the ratification of this treaty" to the end of this language, thereby limiting "the prohibition of removal to all such property as had been originally captured in the forts and places, and should remain there at the exchange of the ratifications." Adams conceded that if the treaty had "been assented to in this form by the American plenipotentiaries, and ratified by their Government, it would have warranted the construction which the British commanders have given to the article as it was ultimately agreed to." However, the Americans had instead proposed transposing the limiting phrase so that it followed the words "public property" but preceded the clause regarding private property, and the British commissioners had agreed to this proposal. Thus, Adams argued, "the American plenipotentiaries admitted, with regard to artillery and public property, the limitation which was proposed by the British ...., but . . . they did not assent to it with regard to slaves and private property." Moreover, "this proposed transposition of the words" gave "the British plenipotentiaries and Government ... full notice of the views of the other contracting party" regarding "the generality of the prohibition to carry away slaves and private property, while acquiescing in a limitation with respect to artillery and public property." Therefore, Adams concluded, "in evacuating all places within the jurisdiction of the United States, and in departing from their waters, the British commanders were bound not to carry away any slaves, or other private property of the citizens of the United States." 68 In short, Adams argued that Baker's assertion that the British commissioners never would have agreed to the treaty if they had known that it would require their country to return runaway slaves to the Americans was ridiculous. By proposing the transposition of the limiting clause, the Americans had put the British on notice that they expected the return of their slaves as a part of the return to peace, and by agreeing to this transposition, the British had accepted the proposed condition.

When Adams made his case to Lord Liverpool, the Prime Minister, in person, Liverpool rejected Adams's discussion of the treaty's drafting history out of hand, insisting that "although the intentions of the parties might be developed by reference to the course of the negotiations, yet the ultimate construction must be upon the words of the treaty as they stood." Seeing that his historical arguments were getting him nowhere, Adams then appealed to the laws of war. He explained that the American negotiators at Ghent, himself included, had been intent on securing "the restoration of all property, including slaves, which, by the usages of war among civilized nations, ought not to have been taken. All private property on shore was of that description. It was entitled, by the laws of war, to exemption from capture. Slaves were private property." Lord Liverpool responded with a moral argument, distinguishing slaves from other forms of private property. " $[\mathrm{A}]$ table or a chair, for instance, might be taken and restored without changing its condition, but a living and human being was entitled to other considerations." Adams replied to Liverpool's moral point in purely legalistic terms: though he conceded "the principle" that "a living, sentient being, and still more a human being, was to be regarded in a different light from the inanimate matter of

${ }^{68} \mathrm{Mr}$. Adams to Lord Castlereagh (Aug. 9, 1815), in 4 American State Papers: Foreign Relations, supra note 24 , at 115,116 . 
which other private property might consist," he insisted that "the treaty had marked no such distinction." 69

Eventually, the British put forth a detailed rebuttal to the United States' textual argument. On October 24, Lord Bathurst, the British Secretary of State for War and the Colonies, wrote to Adams to share his opinion regarding "the construction that has been given to the context of the article in question by the Government of the United States." Bathurst explained that, under Monroe's construction, "the words 'carrying away,' which, in the preceding part of the sentence, apply to the restitution of public property, apply equally to the restitution of private property." But, Bathurst declared, "if the words 'carrying away' apply to private as well as public property, how entirely arbitrary it is to say that the intervening words," namely the "originally captured" phrase, "do apply to the one, and do not apply to the other, although the words 'carrying away' grammatically govern both." He found it "impossible" to read the treaty as "placing private property on the same footing as ... public property" in some cases and "establishing dissimilar conditions" for the two in others "without such omissions and interpolations as the undersigned is persuaded that it is not the intention of the American Government to maintain." 70

When news of the British government's refusal to return the refugee slaves reached the United States, Southern elites were furious. "The palpable violation of the treaty by the British officers," Monroe wrote to Adams, had "excited a sensibility" among Southern planters "which need not be described." Monroe reported that Southern slaveholders expected "[a] vigorous effort of the Government to obtain justice." Recognizing that in all likelihood too much time had passed for the runaway slaves themselves to be returned to the United States, Monroe instructed Adams to establish "the principle ... that the British Government will pay for the slaves carried off in violation of the treaty." He left his minister little room for discretion: "It cannot be doubted that the British Government will make a just indemnity to the owners for the slaves who were carried from the United States by the British officers." 71

Adams dutifully set to work. Upon receiving Lord Bathurst's letter in October, he had thought it best to let some time pass before initiating a new round of complaints. But in light of Monroe's sense of urgency, Adams raised the issue again in February 1816, writing to Lord Castlereagh, the British foreign minister, and reiterating his arguments that both "the rules of grammar and the intentions of the parties" supported the United States' claims. ${ }^{72}$

At this point, the British, without quite acknowledging that they were doing so, made a concession to the Americans. Though Castlereagh declared that he could "never admit that construction of the article to be the true one which would apply to the restoration of slaves a different rule from that applicable to private property" when he wrote back to Adams in April,

\footnotetext{
${ }^{69}$ Mr. Adams to the Secretary of State [Monroe] (Aug. 22, 1815), in 4 American State Papers: Foreign RELATIONS, supra note 24, at 116, 117.

${ }^{70}$ Lord Bathurst to Mr. Adams (Oct. 24, 1815), in 4 American State Papers: Foreign Relations, supra note 24, at 119, 119-21 [hereinafter Lord Bathurst to Mr. Adams].

${ }^{71}$ The Secretary of State [Monroe] to Mr. Adams (Nov. 16, 1815), in 4 American State Papers: Foreign Relations, supra note 24, at 121, 121; The Secretary of State [Monroe] to Mr. Adams (Nov. 20, 1815), in 4 American State Papers: Foreign Relations, supra note 24, at 121, 121.

${ }^{72} \mathrm{Mr}$. Adams to the Secretary of State [Monroe] (Feb. 17, 1816), in 4 American State Papers: Foreign Relations, supra note 24, at 122, 122; Mr. Adams to the Right Honourable Lord Viscount Castlereagh, His Majesty's Principal Secretary of State for the Department of Foreign Affairs (Feb. 17, 1816), in 4 AMERICAN State Papers: Foreign Relations, supra note 24, at 122, 122-23.
} 
he nonetheless stated that his government was prepared to indemnify the Americans for some runaway slaves. Specifically, he asserted that the British did not reject the United States' claims "to indemnification for slaves or private property belonging to their citizens, which can be proved to have been in places directed to be restored by the treaty of Ghent, at the date of the exchange of the ratifications, and to have been afterwards removed." Crucially, he did not limit this statement to slaves who had been originally captured in these places, as Captain Clavelle, Admiral Cockburn, Anthony St. John Baker, and Lord Bathurst had done before him. However, he denied "that the United States can have any claim to property not actually in the places which, by the stipulations of the treaty, were to be restored at the time therein." After all, that which "had been previously removed . . could not be carried away." Therefore, Castlereagh argued, "a removal previous to the ratification of the treaty" would "bar the claim of the United States, without reference either to the distance which the property had been removed, to the actual state of the property, whether on shipboard or on British territory, or to the length of time which had elapsed since its removal." Thus, he concluded, he would be "most happy to attend to any representation on the part of the United States which may have for its object the restoration or indemnification for the loss of property [British] citizens actually removed from places within the territory of the United States subsequent to the ratification of the treaty," but he would not "consider any property which had been, previous to the ratification of the treaty, removed on shipboard, as property forming a subject of such representation." ${ }^{33}$ Hence, the British made a concession to the United States, but drew a line in the sand while doing so: they would compensate the United States for slaves they had carried away from American land after the end of the war, but would not hand over a penny for slaves who had been onboard British ships at war's end, even ships docked in American waters.

The United States did not find Lord Castlereagh's offer satisfactory. Though it would entithe the United States to receive indemnification for the persons who had left Tangier Island with Captain Clavelle after the treaty's ratification, and those who had done the same from Cumberland Island with Admiral Cockburn, the Americans insisted that they were also entitled to compensation for the formerly enslaved persons who were on British ships located in American waters at the time of the treaty's ratification. After all, the Americans believed that "such of our harbors and waters as were in the possession of the British at the date of the ratifications were strictly within the meaning of places to be restored." Accordingly, "the British were bound not to have carried away any slaves who were then on board British vessels lying within any such harbors or waters."74

By May, further negotiations had stalled. As Monroe acknowledged, neither party seemed likely to budge. There was "no reason," he wrote, "why the United States should yield to the opinion of Great Britain, more than that Great Britain should yield to that of the United States." And so Secretary Monroe instructed Adams to propose an arbitration. What would happen, he asked, if the two countries were to "refer the question to the decision of

\footnotetext{
${ }^{73}$ Lord Castlereagh to Mr. Adams (Apr. 10, 1816), in 4 American State Papers: Foreign Relations, supra note 24, at 125, 125-26 [hereinafter Lord Castlereagh to Mr. Adams].

${ }^{74}$ Messrs. Gallatin and Rush to the Secretary of State [Adams] (Oct. 20, 1818), in 4 American State Papers: Foreign Relations, supra note 24, at 380, 381 [hereinafter Messrs. Gallatin and Rush to the Secretary of State [Adams]].
} 
some friendly Power"?75 After all, other disputed questions under the Treaty of Ghent had been referred to arbitrators. A dispute over islands in the Bay of Fundy, for example, had been sent to a commission built into the treaty. ${ }^{76}$ The treaty sent two boundary questions to commissions, too. When the commissions were unable to deliver effective answers, the parties eventually referred one of the questions to William I of the Netherlands, who resolved it in 1831. ${ }^{77}$ The second boundary question, relating to the border between the United States and Canada running west from the Great Lakes to the Rocky Mountains, would not be resolved until 1842 in the Webster-Ashburton Treaty. ${ }^{78}$

Adams followed through on Monroe's suggestion in September, suggesting to Castlereagh that the "question should be submitted to the decision of some friendly sovereign." 79 Lord Castlereagh never responded. ${ }^{80}$ However, after the election of 1816 elevated Monroe to the presidency, new Secretary of State John Quincy Adams instructed Richard Rush, his replacement as American minister to Great Britain, to renew the arbitration proposal. This time the British accepted.

British diplomats initially suggested referring the matter to commissioners from the two respective countries as they had with the boundary disputes. ${ }^{81}$ The treaty commissions had already floundered, however. And so eventually, in a convention signed on October 20,1818 , the two countries agreed to refer their "differences to some friendly sovereign or state" and "to consider the decision of such friendly sovereign or state to be final and conclusive on all the matters referred." 82 The question of indemnification for the runaway slaves of the War of 1812 would be resolved through international arbitration.

Reflecting later on the choice the two countries made to arbitrate their dispute, John Quincy Adams observed that the "reference of a question upon the construction of an article of a treaty to a third party is unusual, but not unexampled." 83 Indeed, the practice of resolving interstate disputes through arbitration emerged as early as the fifth century B.C. with a series of cases connected to the Peloponnesian War between Athens and Sparta, and during the Middle Ages the Pope and various monarchs regularly presided over international arbitrations. ${ }^{84}$

\footnotetext{
75 The Secretary of State to Mr. Adams (May 21, 1816), in 4 American State Papers: Foreign Relations, supra note 24 , at $126,126$.

76 James L. Tryon, The Advance Made by Treaties of Arbitration, 24 Yale L.J. 56, 57-58 (1914).

77 Francis M. Carroll, A Good and Wise Measure: The Search for the Canadian-American Boundary, 1783-1842 (2001); Francis M. Carroll, The Search for the Canadian-American Boundary Along the Michigan Frontier, 1819-1827, 30 Mich. Hist. Rev. 77 (2004); John P. D. Dunbabin, The 1831 Dutch Arbitration of the Canadian-American Boundary Dispute: Another View, 75 New Eng. Q. 622 (2002); Oona Hathaway, Treaties' End, 117 Yale L.J. 1236, 1291 n. 144 (2008).

${ }^{78}$ John Bassett Moore, The United States and International Arbitration, in REPORT OF THE AMERICAN HISTORICAL Association for 1891, 65, 68-70 (Washington, Gov’t Prtg. Off. 1892).

${ }^{79} \mathrm{Mr}$. Adams to Lord Castlereagh (Sept. 17, 1816), in 4 American State Papers: Foreign Relations, supra note 24 , at $126,126$.

${ }^{80}$ Viscount Castlereagh to Mr. Adams (Sept. 28, 1816), in 4 American State Papers: Foreign Relations, supra note 24, at 126, 126.

${ }^{81} \mathrm{Mr}$. Adams to Messrs. Gallatin and Rush (July 28, 1818), in 4 American State Papers: Foreign Relations, supra note 24 , at 375,376 .

${ }^{82}$ Convention with Great Britain (Oct. 20, 1818), in 4 American State PaPers: Foreign Relations, supra note 24, at 406, 406-07 [hereinafter Convention with Great Britain].

${ }^{83}$ ADAMS, supra note 50, at 160.

84 L.B. Sohn, International Arbitration in Historical Perspective: Past and Present, in InTERnational Arbitration: Past and Prospects 9, 10-11 (A.H.A. Soons ed., 1990); Jacques Werner, Interstate Political
} 
A new modern era of international arbitration began in 1794, when the United States and Great Britain agreed in the Jay Treaty to submit disputes relating to the U.S.-Canadian boundary, the debts of former British citizens living in the United States, and the British seizure of American ships on the high seas to arbitration. In the aftermath of "the relative success of the arbitrations under the Jay Treaty," the two countries incorporated arbitration provisions into the Treaty of Ghent and eventually the 1871 Treaty of Washington. ${ }^{85}$ Thus, the Jay Treaty "ushered in what can only be regarded as a new age of inter-state arbitration" — an age that was just commencing when the two countries decided to submit their dispute over the meaning of the first article of the Treaty of Ghent arbitration. ${ }^{86}$

The parties ultimately selected the Russian Emperor, Czar Alexander, as their arbitrator. ${ }^{87}$ And at Adams's suggestion, President Monroe selected Henry Middleton, a wealthy planter from South Carolina, to represent the United States in St. Petersburg during the arbitration. ${ }^{88}$ Adams considered Middleton "peculiarly suited for this mission, . . . as being by his great fortune able to bear the expense of residing as a public Minister without starving upon the salary allowed." The South Carolinian possessed one other crucial qualification for this position: he was "from a State the inhabitants of which had suffered most by the loss of slaves." 89

Middleton departed for Russia in June 1820. After a three-month long sojourn in England, during which time he met with Lord Castlereagh and other British diplomats to discuss details of the impending arbitration, and a sightseeing tour in continental Europe, Middleton arrived in Russia in November 1820. The czar, who was out of the country when Middleton arrived, returned to St. Petersburg in June 1821. Middleton and the British representative, Charles Bagot, spent the next several months presenting their arguments and counterarguments to the czar. ${ }^{90}$ The emperor's consideration of the issue was

Arbitration: What Lies Next?, 9 J. Int'l Arb. 69, 69-70 (1992); 1 Gary Born, International Commercial Arbitration 8-14 (2009). See generally Jackson H. Ralston, International Arbitration from Athens to LOCARNO 153-191 (1929).

${ }^{85}$ Werner, supra note 84, at 70-71 (1992). See also MAnley O. Hudson, International Tribunals: PAST AND FutUre 3-5 (Lawbook Exchange LTD 2003) (1944).

${ }^{86}$ BORN, supra note 84, at 13. See also RALSTON, supra note 84, at 191 ("The modern era of arbitral or judicial settlement of international disputes, by common accord among all writers on the subject, dates from the signing on November 19, 1794, of the Jay Treaty between Britain and the United States.”).

87 The Americans had suggested that the 1818 convention specifically name the Russian emperor as arbitrator, but the British had rejected the idea "on the ground that, if he should refuse to act, the agreement would become null." Messrs. Gallatin and Rush to the Secretary of State [Adams], supra note 74. However, by the end of 1820 , President Monroe was able to officially inform Congress that the czar had indeed agreed to arbitrate the dispute. Message of the President of the United States at the Commencement of the Sixteenth Congress, Second Session (Nov. 15, 1820), in 4 American State Papers: Foreign Relations, supra note 24, at 644, 645. See also Moore, supra note 3, at 358-59. For a discussion of why the two countries selected the Russian czar to serve as arbitrator, see infra text accompanying notes 151-154.

${ }^{88}$ The scion of one of his state's most prominent families (his grandfather had served briefly as president of the First Continental Congress and his father had signed the Declaration of Independence), Middleton served as a state representative and state senator before being elected to the governorship and then Congress. He possessed enormous wealth, owning over 1,000 slaves scattered across various plantations. James J. Farsolas, An American Ambassador at the Court of St. Petersburg, Russia: Henry Middleton of South Carolina and John Capodistrias (18211827), 39 BALKAN STUD. 15, 16-22 (1998).

894 John Quincy Adams, Memoirs of John Quincy Adams, Comprising Portions of His Diary from 1795 TO 1848, at 474 (Charles Francis Adams ed., Philadelphia, J.B. Lippincott \& Co., 1875).

${ }^{90}$ Farsolas, supra note 88, at 23-31; Harold E. Berquist, Jr., Henry Middleton and the Arbitrament of the AngloAmerican Slave Controversy by Tsar Alexander I, 82 S.C. Hist. MAG. 20, 22-29 (1981). 
delayed by political unrest in Europe; revolutionary movements in Spain, Italy, and Greece occupied much of Alexander's attention during 1821. ${ }^{91}$ But on April 22, 1822, Alexander finally announced his decision.

\section{The First PuZZle}

\section{A. "This Award of His Imperial Majesty"}

The czar made clear that, in rendering his verdict, he had not considered issues relating to morality, the treaty's drafting history, or the laws of war. Rather, the emperor had "devot[ed] all his attention to the examination of the grammatical question," "confin[ing] himself to following the rules of the language employed in drawing up the act." 92 The seven-year long legal-diplomatic battle would turn on the Russian czar's interpretation of the English language: an interpretation written in French, the international language of diplomacy, and based on briefs that the parties had set forth in the same. ${ }^{93}$ The official translation of the French-language opinion back into the English read as follows:

The Emperor is of opinion "that the question can only be decided according to the literal and grammatical sense of the first article of the treaty of Ghent."

As to the literal and grammatical sense of the first article of the treaty of Ghent:

Considering that the period upon the signification of which doubts have arisen is expressed as follows:

"All territory, places, and possessions, whatsoever, taken by either party from the other during the war, or which may be taken after the signing of this treaty, excepting on the islands hereinafter mentioned, shall be restored without delay and without causing any destruction or carrying away any of the artillery of other public property originally captured in the said forts or places, and which shall remain therein upon the exchange of the ratifications of this treaty, or any slaves or other private property ...."

Considering that, in this period, the words originally captured, and which shall remain therein upon the exchange of the ratifications, form an incidental phrase which can have respect, grammatically, only to the substantives or subjects which precede;

That the first article of the treaty of Ghent thus prohibits the contracting parties from carrying away from the places of which it stipulates the restitution only public property which might have been originally captured there, and which should remain therein upon the exchange of the ratifications, but that it prohibits the carrying away from there same places any private property whatever;

That, on the other hand, there these prohibitions are solely applicable to the places of which the article stipulates the restitution:

The Emperor is of opinion:

"That the United States of America are entitled to a just indemnification from Great

${ }^{91}$ Farsolas, supra note 88, at 29-30; Berquist, supra note 90, at 25.

92 Count Nesselrode to Mr. Middleton (Apr. 22, 1822), in 5 American State Papers: Foreign Relations 219, 219-20 (William S. Hein \& Co., 1998) (1858).

${ }^{93}$ Berquist, supra note 90, at 28 n. 19. See, e.g., Henry Middleton, Précis de la Question ou Exposé Abrégé du Différend qui Est Survenu par Rapport au Premier Article du Trait'de Gand, entre les États-Unis D’Amérique et L’Angleterre (1821), N4, Russian Foreign Ministry Archive. 
Britain for all private property carried away by British forces; and, as the question regards slaves more especially, for all such slaves as were carried away by the British forces from the places and territories of which the restitution was stipulated by the treaty, in quitting the said places and territories."

"That the United States are entitled to consider as having been so carried away all such slaves as may have been transported from the above mentioned territories on board of the British vessels within the waters of said territories, and who, for this reason, have not been restored."

"But that, if there should be any American slaves who were carried away from territories of which the first Article of the treaty of Ghent has not stipulated the restitution to the United States, the United States are not to claim an indemnification for the said slaves." The Emperor declares, besides, that he is ready to exercise the office of mediator, which has been conferred on him beforehand by the two States, in the negotiations which must ensue between them in consequence of the award which they have demanded." 94

The award's language was ambiguous on its face. Though he claimed victory for the American side, Adams acknowledged as much in his memoirs, declaring, "The decision is in our favor, but is expressed in language needing explanation more than the paragraph of the article which was in question." 95 Who, then, really won? Adams's caveat has now led to uncertainty in the literature. ${ }^{96}$ And after all, the arbitration (like the passage it aimed to construe) was involved and convoluted at best. But when read closely and in the context of the arguments that each side made in the run-up to the arbitration, an answer emerges. The traditional view is correct. The Russian emperor's award favored the United States.

How do we so conclude? Recall first that the British and the Americans had disagreed most of all over the application of the phrase "originally captured in the said forts or places, and which shall remain therein upon the exchange of the ratifications of this treaty." The Americans had argued that this limitation only applied to public property. ${ }^{97}$ However, the British naval commanders insisted that it also applied to private property, including slaves, and the British government had initially seconded this reading. ${ }^{98}$

The czar firmly came down on the American side of this debate. Alexander found that "the words originally captured, and which shall remain therein upon the exchange of the ratifications, form an incidental phrase which can have respect, grammatically, only to the substantives or subjects which precede." Therefore, he ruled that the treaty "prohibits the contracting parties from carrying away . . . only public property which might have been originally captured there, and which should remain therein upon the exchange of the ratifications, but . . . it prohibits the carrying away from these same places any private property whatever." 99 In short, the

\footnotetext{
${ }^{94}$ His Imperial Majesty's Award (Apr. 22, 1822), in 5 American State Papers: Foreign Relations, supra note 92, at 220, 220 [hereinafter His Imperial Majesty's Award].

956 John Quincy Adams, Memoirs of John Quincy Adams, Comprising Portions of His Diary from 1795 To 1848, at 45 (Charles Francis Adams ed., Philadelphia, J.B. Lippincott \& Co., 1875).

96 See supra text accompanying note 4 (discussing the recent work of Prof. James Oakes).

97 See, e.g., Monroe to Baker, supra note 45, at 106-07.

${ }^{9}$ See Mr. Clavelle to Messrs. Bayly, Graham, and Skinner, supra note 52; Admiral Cockburn to Messrs. Newell and Spalding, supra note 53; Mr. Baker to Mr. Monroe, supra note 49; Lord Bathurst to Mr. Adams, supra note 70.

${ }^{99}$ His Imperial Majesty's Award, supra note 94.
} 
"originally captured" phrase applied to public property but not private property, exactly as the Americans had argued.

Indeed, we have already seen that the British had conceded as much before the dispute went to arbitration. As previously discussed, in April 1816 Lord Castlereagh, the British Foreign Minister, had offered to indemnify the United States for all slaves carried away from "places directed to be restored by the treaty of Ghent" after the treaty's ratification, not just the slaves who had been originally captured in these places. Nonetheless, another point of contention remained between the two sides. Even as he was making the above concession, Castlereagh had asserted that the British would not offer compensation for runaway slaves who had been on British ships docked in American waters at the time of ratification. He insisted that the British had carried away these slaves prior to ratification, on the grounds that British ships were not "places which, by the stipulations of the treaty, were to be restored at the time specified therein." 100 The Americans, as already described, rejected this offer, arguing that "such of our harbors and waters as were in the possession of the British at the date of the ratifications were strictly within the meaning of places to be restored." 101 Accordingly, in the 1818 Anglo-American convention that officially referred the dispute to arbitration, the United States insisted that its citizens were entitled to compensation for all slaves that the British had carried away after the treaty's ratification, "whether such slaves were, at the date aforesaid, on shore, or on board any British vessel lying in waters within the territory or jurisdiction of the United States." 102

Once again, the czar sided with the Americans. His award made clear not only that "the United States of America are entitled to a just indemnification from Great Britain for all private property carried away by British forces" but also that "the United States are entitled to consider as having been so carried away all such slaves as may have been transported from the [places and territories of which the restitution was stipulated by the treaty] on board of the British vessels within the waters of the said territories." 103 Thus, the czar vindicated the United States' decision to reject Lord Castlereagh's offer. Its citizens would receive compensation for all slaves who had been carried away from American territory after the end of the war, regardless of whether those slaves had been on American soil or on British ships docked in American waters. A second point of contention had been resolved in favor of the Americans.

However, a third disagreement remained. The czar's award declared that "the United States are not to claim an indemnification" for "any American slaves who were carried away from territories of which the first article of the treaty of Ghent has not stipulated the restitution to the United States." 104 Did this language mean that the British did not have to compensate the Americans for slaves who had run away from places that the British had never occupied and voluntarily joined the British ranks? The British thought so. Charles Bagot, the British minister to Russia, wrote to Count Nesslerode, the Russian Foreign Minister, to explain the way in which he interpreted the award:

\footnotetext{
${ }^{100}$ Lord Castlereagh to Mr. Adams, supra note 73.

${ }^{101}$ Messrs. Gallatin and Rush to the Secretary of State [Adams], supra note 74.

${ }^{102}$ Convention with Great Britain, supra note 82, at 407.

${ }^{103}$ His Imperial Majesty's Award, supra note 94.

${ }^{104} \mathrm{Id}$
} 
$[\mathrm{H}]$ is Britannic Majesty is not bound to indemnify the United States for any slaves who, coming from places which have never been occupied by his troops, voluntarily joined the British forces, either in consequence of the encouragement which his Majesty's officers had offered to them, or to free themselves from the power of their master-these slaves not having been carried away from places or territories captured by his Britannic Majesty during the way, and, consequently, not having been carried away from places of which the articles stipulated the restitution. ${ }^{105}$

Alas for Bagot, Czar Alexander would not allow the British to claim even this limited victory. The emperor wrote to the parties to clarify his views. "[U]nwilling that the slightest doubt should arise regarding the consequences of his opinion," he made it clear " $t]$ hat in quitting the places and territories of which the treaty of Ghent stipulates the restitution to the United States, his Britannic Majesty's forces had no right to carry away from these same places and territories absolutely any slave, by whatever means he had fallen or come into their power."106 Thus, the emperor ruled that the treaty's language covered all slaves carried away from Britishcontrolled American territory at the end of the war, regardless of whether those slaves had voluntarily run away to the British or the Redcoats had forcibly liberated them.

Oakes cites Bagot's above-quoted statement when he claims that "the British read the czar's decision as a vindication." 107 Oakes's view would be an exaggeration even if Bagot had correctly interpreted the czar's award, for such a ruling would have only represented a minor victory for the British-they would have still been required to compensate the United States for all slaves who had run away from places that the British had occupied and all slaves whom they had forcibly liberated. Yet, as we have just seen, the emperor emphatically contradicted Bagot's reading of his award. Oakes does not discuss this portion of the emperor's response to Bagot. However, he does mention the one limitation that the emperor attached to his clarification. Effectively reiterating the language that had created the ambiguity in the first place, the czar declared:

[I]f, during the war, American slaves had been carried away by the English forces from other places than those of which the treaty of Ghent stipulates the restitution upon the territory, or on board British vessels, Great Britain should not be bound to indemnify the United States for the loss of these slaves, by whatever means they might have fallen or come into the power of her officers. ${ }^{108}$

Oakes reads this language to affirm Bagot's interpretation of the emperor's award. Oakes seems to equate the emperor's statement "that compensation was due to the Americans only for slaves carried away from areas stipulated for restitution in the treaty" to a ruling that the United states was only entitled to indemnification for those slaves who were carried away from the place where they had been originally captured, as the British naval commanders had argued in the war's immediate aftermath. ${ }^{109}$ However, the czar had already made it

\footnotetext{
105 Count Nesselrode to Mr. Middleton (Apr. 22, 1822), in 5 American State Papers: Foreign Relations, supra note 92, at 221, 221 [hereinafter Count Nesselrode to Mr. Middleton]; see also Annex B, FO 93/8/11, The National Archives of the UK (in French).

${ }^{106}$ Count Nesselrode to Mr. Middleton, supra note 105 (emphasis added).

107 OAKES, supra note 4, at 141.

108 Count Nesselrode to Mr. Middleton, supra note 105.

${ }^{109}$ OAKES, supra note 4, at 142.
} 
clear in his initial ruling that the originally captured limitation applied only to public property, not to private property (and indeed, Lord Castlereagh had conceded as much in April 1816). Thus, it makes more sense to read the emperor's above statement (and the similar language in his initial ruling) as merely declaratory of what could have gone without saying: the United States was not entitled to compensation under the Treaty of Ghent for slaves carried away from places where the Treaty of Ghent did not apply. This provision meant that the United States could not claim indemnification for slaves that the British had removed from the United States before the end of the war or from territory that did not belong to the United States at the time the war ended.

Oakes finds support for his argument in Count Nesselrode's statement accompanying the emperor's clarification, which appears to affirm Bagot's interpretation. After informing the parties of the emperor's response to Bagot's note, he declares himself "convinced . . . that such is also the sense which Sir Charles Bagot attached to his observation." 110 However, given the way in which the emperor had just clearly contradicted Bagot's interpretation, we can easily dismiss these words as mere diplomatic niceties. After all, the language of both the emperor's award and his subsequent clarification are clear, at least when read closely and in the context of the negotiations that had occurred over the previous seven years. Alexander ruled that the Treaty of Ghent required the British to indemnify the Americans for each and every slave carried away from British-controlled American territory after the end of the war-regardless of whether the slave had originally reached British lines in that location, regardless of whether the slave was on a ship or on land, regardless of where in the United States the slave had originated from, and regardless of whether the slave had voluntarily joined the British ranks.

So far, the analysis here has relied almost entirely on close readings of the official diplomatic correspondence, which has been available to scholars in official American State Papers volumes for nearly two centuries. But unpublished materials in the U.S. National Archives hold further striking evidence on the key question. It turns out that Castlereagh made plans for an adverse outcome even before the czar issued his decision. The way in which the United States and Great Britain ultimately implemented the emperor's award closely matches the process Castlereagh planned to follow in the event he lost the case.

When Middleton discussed the details of the impending arbitration with Castlereagh during his 1820 visit in London, the British foreign minister had proposed a mechanism for implementing the czar's decision should it go in favor of the United States. Castlereagh suggested a joint commission consisting of two judges and two arbitrators, one of each from each of the two countries. The two judges would fix the indemnity owed for each carried away slave, settling "all differences if they can agree." "[I]n the case of disagreement of the judges," one of the arbitrators was to be chosen by lottery ("called in by Lot") to assign the amount owed. ${ }^{111}$ Ironically, Castlereagh drew his proposed arbitration mechanism directly from the

${ }^{110}$ Id.; Count Nesselrode to Mr. Middleton, supra note 105.

${ }^{111}$ Henry Middleton to John Quincy Adams (Sept. 15, 1820), Diplomatic Dispatches, Russia, VIII, \#2, U.S. National Archives. See also Berquist, supra note 90, at 23. Similarly, Richard Rush, the American minister to the Court of St. James', explained to Middleton that if "the decision of the Emperor of Russia . . . be in favor of Great Britain," then the issue of compensation for the runaway slaves would have "come to a close"; however, if "the decision be in favor of the United States, it will form only the commencement of proceedings." Richard Rush to Henry Middleton (Aug. 10, 1820), Diplomatic Dispatches, Russia, VIII, \#1, Paper A, U.S. National Archives. 
structure of the so-called "mixed commissions" by which the United Kingdom and its treaty partners had begun to condemn suspected slave trading vessels just three years earlier. ${ }^{12}$ The important point here, however, is that in the wake of the czar's April decision, the United States and Britain proceeded almost exactly as Castlereagh had proposed to move forward in the event of a U.S. victory. The process adopted by the United States and the United Kingdom after the czar's decision reveals that both sides viewed the decision as a victory for the United States.

On July 12, 1822, with the czar once again serving as a mediator, Middleton and Charles Bagot, the British representative in Russia, signed a convention "for the purpose of carrying into effect this award of his Imperial Majesty." The convention spelled out in great detail "the mode of ascertaining and determining the value of slaves and of other private property which may have been carried away in contravention of the treaty of Ghent, and for which indemnification is to be made to the citizens of the United States." And Middleton and Bagot followed Castlereagh's pre-resolution plan from 1820 nearly word-for-word. Under the terms of the convention, each country would respectively appoint one commissioner and one arbitrator, and these four individuals would "meet and hold their sittings as a board in the city of Washington." The Board would have two tasks. First, the commissioners and arbitrators together would "examine the testimony which shall be produced under the authority of the President of the United States" in order to determine an "average value" that "shall in all cases serve as a rule for the compensation to be awarded for each and every slave for whom it may be afterwards be found that indemnification is due." Then, once "the average value of slaves shall have been ascertained and fixed," the two commissioners would examine "the claims which are to be submitted to them," though they would only "take cognizance of" those claims which the American Secretary of State included on a "definitive list of the slaves and other private property for which the citizens of the United States claim indemnification."

To support this effort, the British promised to provide the commissioners with "all the evidence of which His Majesty's Government may be in possession . . . of the number of slaves carried away." If the two commissioners nonetheless disagreed about the merits of a particular claim, the convention invoked the lottery procedure from the British mixed-commission treaty courts: "they shall draw by lot the name of one of the two arbitrators, who, after having given due consideration to the matter contested, shall consult with the Commissioners and a final decision shall be given, conformably to the opinion of the majority of the two Commissioners, and of the arbitrator so drawn by lot."113

Oakes tells the story differently. According to him, in the aftermath of the arbitration, "the Americans acted as though the emperor had ruled in their favor and proceeded to draw up elaborate lists of slaves carried away from places not specified for restitution in the treaty."114

\footnotetext{
112 See Martinez, Slave Trade, supra note 5, at 69; Alston, supra note 5, at 2047.

${ }^{113}$ Convention with Great Britain under the Mediation of Russia, Explanatory of the First Article of the Treaty of Ghent, Concerning Indemnity for Slaves Carried from the United States by the British Forces in 1812-1814 (July 12, 1822), in 5 American State Papers: Foreign Relations, supra note 92, at 214, 214-17 [hereinafter St. Petersburg Convention]; see also Convention Signed at St. Petersburg on the 12 July/30 June by the Plenipotentiaries of His Imperial Majesty, of His Britannic Majesty, and of the President of the United States of America, for the Purpose of Carrying into Effect the Emperor's Decision Upon the Contested Point Arising out of the 1 st Article of the Treaty of Ghent, Referred to His Imperial Majesty's Arbitration, FO 93/8/11, The National Archives of the UK.

${ }^{114}$ OAKES, supra note 4, at 142.
} 
However, Oakes ignores the fact that the British themselves had signed a bilateral convention implementing the czar's award that instructed the Americans to create a "definitive list of the slaves and other private property" that the British had carried away in violation of the Treaty of Ghent. ${ }^{115}$ More importantly, Oakes's analysis proceeds without the benefit of the archival materials showing that the stipulations of this convention almost precisely mirrored the mechanism that the British foreign minister had proposed prior to the arbitration to govern in the event of a U.S. victory. If the award's plain language does not make it sufficiently clear that Alexander's decision favored the United States, the manner in which the two sides executed the award provides nearly conclusive proof.

\section{B. The Chaos of the Claims Commisson}

The British and American governments officially ratified the convention to carry the emperor's award into effect in January 1823. The Board met for the first time that August. ${ }^{116}$ In another demonstration of slaveholder domination in American foreign policy, the United States appointed two Southerners to sit on the Board-Langdon Cheves, a former Congressman from South Carolina, would serve as commissioner, while Henry Seawell of North Carolina would serve as arbitrator. For Britain, George Jackson and John McTavish would serve as commissioner and arbitrator, respectively. ${ }^{117}$

Over the course of the next thirteen months the Board collected and reviewed evidence submitted by both the United States and Great Britain regarding the average value of slaves at the time that the Treaty of Ghent was ratified. Then, on September 11, 1824, the Board unanimously agreed to value slaves carried away from Louisiana at $\$ 580$, slaves carried away from Alabama, Georgia, and South Carolina at \$390, and slaves carried away from Virginia, Maryland, Mississippi, Delaware, and the District of Columbia at $\$ 280 .{ }^{118}$

The precise, particularized, and unanimous way in which the commissioners were able to fix the value of slaves carried away from various states testifies to the depth and robustness of markets in slaves in the 1820s. As Walter Johnson reminds us in his study of the New Orleans slave market, slaves were people whose "bodies . . . could be bought and sold in the market." 119 Indeed, Johnson argues that "the story of antebellum slavery" is, in no small part, "a story of . . . human beings broken down into parts and recomposed as commodities." 120 Daina Ramey Berry's recent The Price for Their Pound of Flesh develops the idea further; slaves had prices, which were readily ascertainable on the market. ${ }^{121}$ As Caitlin Rosenthal explains in her new book Accounting for Slavery, slaveholders "developed an array of ways to value and compare human capital." 122 The enslaved people who had sought refuge behind British lines during the War of 1812 had long since found their freedom, never to return to their masters. Nonetheless, because human beings were a market good in the Old South, the Board could

\footnotetext{
115 St. Petersburg Convention, supra note 113.

${ }^{116}$ Exchange of Ratifications, FO 94/7, The National Archives of the UK; Moore, supra note 3, at 366.

117 Moore, supra note 3, at 366, nn.1-2.

${ }^{118} I d$. at 370.

119 Walter Johnson, Soul by Soul: Life Inside the Antebellum Slave Market 16 (1999).

$120 \mathrm{Id}$. at 3.

121 Daina Ramey Berry, The Price for Their Pound of Flesh (2016); see also Sexuality and Slavery: Reclaiming Intimate Histories in the Americas (Daina Ramey Berry \& Leslie M. Harris eds., 2018).

122 Caitlin Rosenthal, Accounting for Slavery: Masters and Management 2 (2018).
} 
determine, with great specificity, a dollar amount that would enable aggrieved slaveowners to buy replacement slaves in the market and thereby make themselves whole.

For all this, the story of the dispute over the Treaty of Ghent's first article remained far from over. On September 13, 1824, Commissioners Cheves and Jackson notified Secretary of State Adams that, having determined the average values of the slaves, they were now ready to receive the "definitive list" of slaves that the British had carried away. Adams submitted the list on December 10, and on December 14, the Board resolved that it would "on each morning of their meeting, sit with open doors for the purpose of receiving proofs, motions, and other communications from the claimants." 123 However, as Henry Clay, who became Secretary of State after Adams won the bitterly fought presidential election of 1824, soon found out, the Board's task would not prove easy.

In May 1825, Clay wrote to Rufus King, the new American minister to Great Britain, to inform him that " $[\mathrm{t}]$ he proceedings of the Board have been arrested by . . . Mr. Jackson." The British commissioner, Clay explained, "has manifested throughout the most impracticable disposition," altogether failing to demonstrate the "spirit of mutual concession and accommodation" necessary for the joint commission to function. First, Jackson had made unreasonable demands regarding "every preliminary question about the forms of trial, the authentication of evidence, . . . and the rules of proceeding" that the Board would use when evaluating claims. ${ }^{124}$ Moreover, Jackson rejected the claims of Louisiana slaveholders whose human property had been carried away from Dauphin Island, a barrier island in Mobile Bay, on the grounds that "Dauphin Island was not an appendage of Louisiana, but of West Florida, and therefore belonged to Spain at the period of the exchange of the ratifications of the treaty of Ghent."125 Additionally, Jackson rejected slaveholders' claims for interest, arguing that, under the St. Petersburg Convention, the Board only had the authority to determine the average value of the slaves carried away; if the commissioners were also supposed to assign an interest rate to the value of the slaves, the convention would have expressly said so. ${ }^{126}$ More than anything else, however, it was Jackson's unwillingness to "execute the fifth article of the convention" by submitting these disputes to the arbitrators, Seawell and

\footnotetext{
${ }^{123}$ Minutes of the Board (Dec. 14, 1824), American Claims 1823-1825, FO 353/92, The National Archives of the UK. See also Moore, supra note 3, at 371.

${ }^{124}$ H. Clay to R. King (May 10, 1825), in 6 American State Papers: Foreign Relations 339, 339 (William S. Hein \& Co., 1998) (1859) [hereinafter H. Clay to R. King].

${ }^{125} \mathrm{Id}$. at 340. Clay maintained not only that the United States had held title to Dauphin Island since the Louisiana Purchase of 1803 but also that the question of title was irrelevant - for purposes of determining compensation under the czar's award, the only important question was whether or not the United States possessed the island at the time of the treaty's ratification. See Mr. Clay to Mr. Vaughan (Oct. 12, 1826), in 6 American STATE PAPERS: Foreign Relations, supra note 124, at 750, 751. The dispute over Dauphin Island thus illustrates the significance of the czar's seemingly declaratory pronouncement that the United States could not claim indemnification for "any American slaves who were carried away from territories of which the first Article of the treaty of Ghent has not stipulated the restitution to the United States." His Imperial Majesty's Award, supra note 94. The stakes of the dispute over the application of the treaty to Dauphin Islands were high, for, as Clay explained, it "includes all the slaves belonging to citizens of Louisiana, to which the highest average price has been affixed." Mr. Clay to Mr. Vaughan (Apr. 19, 1826), in 6 American State Papers: Foreign Relations, supra note 124, at 748,748 .

${ }^{126}$ Minutes of the Board (Mar. 16, 1825), American Claims 1823-1825, FO 353/92, The National Archives of the UK. See also Moore, supra note 3, at 375-76.
} 
McTavish, that frustrated Clay. ${ }^{127}$ After all, Clay explained, "[i]f, when the two Commissioners are divided in opinion, the British Commissioner refuses the reference for which provision is made in the fifth article, that refusal is tantamount to a decision in favor of Great Britain." 128

As disputes dragged on, the work of the Board ground to a halt. By the time the Board adjourned for the summer on April 27, 1825, it had become clear to Clay that, thanks to the British commissioner's refusal to call in an arbitrator to resolve these issues, "no practical benefit is likely to flow" from the work of the commission. ${ }^{129}$ Accordingly, Clay decided to pursue other methods of procuring indemnification for American slaveholders. If necessary, he was willing to resubmit the whole issue to the emperor. However, he hoped that such an extreme measure would not prove necessary. Having heard rumors that that the British government was anxious to end the whole affair "by an agreement fixing upon some gross amount for all the indemnities which the convention promises," Clay instructed King to "sound the British Government upon the subject" and, if possible, make such an arrangement. ${ }^{130} \mathrm{He}$ calculated the total value of the American claims, including interest, to be $\$ 2,693,120$. However, since many of these claims appeared questionable at best and the interest issue remained unresolved, Clay viewed " $\$ 1,151,800$ as the highest sum which it may be fairly presumed would be awarded by the commission if it be not abolished," and he told King that he should consider that number "as the minimum to which you can fall." 131 And indeed, in their most recent appropriations the British parliament had set aside $£ 250,000$ sterling to cover the commission's awards. "This sum being very near the same as that to which you are limited," Clay anticipated that King would "have no difficulty in coming to the agreement with the British Government which you are now authorized to conclude."132

The British initially rejected the American settlement offer, and the Board's stalemate continued into 1826. ${ }^{133}$ But in August, British foreign minister George Canning raised the issue of settlement with Albert Gallatin, the former Secretary of the Treasury and now the new American representative in London. By November the two countries had signed a convention agreeing to resolve all American claims arising from the first article of the Treaty of Ghent for $\$ 1,204,960 .{ }^{134}$ On December 20, President John Quincy Adams, who had represented the

${ }^{127}$ H. Clay to R. King, supra note 124. Article V of the St. Petersburg Convention called for the commissioners to submit all disagreements over "any particular case under examination, or . . . upon any question which may result from the stipulations of the convention," to one of the two arbitrators, as drawn by lot. St. Petersburg Convention, supra note 113, at 217. Jackson had refused to submit to arbitration the questions relating to omitted claims, Dauphin Island, and interest. Moore, supra note 3, at 373, 377.

${ }^{128} \mathrm{H}$. Clay to R. King, supra note 124 , at 342.

${ }^{129}$ Id.

${ }^{130}$ Id.

131 Id. at 343.

${ }^{132}$ Id. See also Financial Statement, Morning Post, Mar. 1, 1825, British Library Newspapers, available at http://tinyurl.galegroup.com/tinyurl/8pmtBX (containing the text of a speech in which the British Chancellor of the Exchequer explained to Parliament that "we shall be obliged to pay to the United States of America by virtue of the Treaty of Ghent ... pecuniary amends for certain slaves" and that the value of these slaves "would amount to not less that $£ 250,000 ”)$.

${ }^{133} \mathrm{Mr}$. Vaughan to Mr. Clay (Apr. 12, 1826), in 6 American State Papers: Foreign Relations, supra note 124, at 746, 746; H. Clay to Albert Gallatin (June 21, 1826), in 6 American State Papers: Foreign Relations, supra note 124 , at 343, 343-44.

${ }^{134}$ Mr. Gallatin to Mr. Clay (Aug. 19, 1826), in 6 American State Papers: Foreign Relations, supra note 124, at 346, 346-47; Convention with Great Britain (Nov. 13, 1826), 6 American State Papers: Foreign 
United States during the ongoing dispute as a negotiator at Ghent, minister plenipotentiary to the Court of St. James, and Secretary of State, transmitted the convention to the Senate for its advice and consent. The two countries exchanged ratifications of the convention in London on February 6, 1827. ${ }^{135}$ At last, a dozen years after it began, the dispute between the United States and Great Britain over the slaves carried away in the aftermath of the War of 1812 had come to an end. ${ }^{136}$

\section{The Many Functions of International Arbitration}

Surely there was a better way. The cumbersome arbitration procedures by which the United States and the United Kingdom worked out their dispute over the slaves of the War of 1812 took more than a decade to work out. Why had the United Kingdom and the United States agreed to arbitrate their disagreement if the result was such delay? Castlereagh was, as we have seen, preparing for defeat in the arbitration even before the czar issued his decision. ${ }^{137}$ Why would the United Kingdom have agreed to send a question to arbitration when, as we have also seen, it was an almost-certain loser? Indeed, why send the dispute to arbitration at all when British strength meant they could instead have simply ignored the American complaints?

Put in the most general way, the answers to such a question are as many and as eclectic as the field of international relations. ${ }^{138}$ But the diplomatic correspondence supplies a striking and illuminating answer.

Relations, supra note 124, at 355, 355. See also Convention Between His Britannic Majesty and the United States of America-Signed at London, November 13th, 1826, FO 93/8/13, The National Archives of the UK. See generally Mr. Gallatin to Mr. Clay (Sept. 12, 1826), in 6 American State Papers: Foreign Relations, supra note 124, at 347-48; Mr. Gallatin to Mr. Clay (Sept. 13, 1826), in 6 American State Papers: Foreign Relations, supra note 124, at 349-50; Mr. Gallatin to Secretary of State [Clay] (Sept. 16, 1826), in 6 American State Papers: Foreign Relations, supra note 124, at 350; Mr. Gallatin to Mr. Clay (Nov. 11, 1826), in 6 American State Papers: Foreign Relations, supra note 124, at 351-53; Mr. Gallatin to Mr. Clay (Nov. 13, 1826), in 6 American State Papers: Foreign Relations, supra note 124, at 353-54.

135 John Quincy Adams to the Senate of the United States (Dec. 20, 1826), in 6 American State Papers: Foreign Relations, supra note 124, at 346; MoOre, supra note 3, at 382.

${ }^{136}$ Of course, the problem remained of how to distribute the money to the more than 1,000 individual American claimants. Congress established a commission to carry out the task, authorizing it to pay out $75 \%$ of each approved claim, with the remainder of the claim to be paid out of whatever funds remained after all claims had been judged. In order to ensure that they would be fully compensated, slaveholders from Georgia and Louisiana began aggressively questioning the validity of claimants from Maryland and Virginia, arguing that their slaves had been carried away before the treaty's ratification. Their efforts resulted in little success, however, and funds ultimately ran out well before all claims could be fully paid. See FeHrenbacher, supra note 2, at 96-97; WITT, supra note 2, at 77; OAKES, supra note 4, at 143-46.

137 See supra text accompanying note 111.

138 See, e.g., Peter Gourevitch, The Second Image Reversed: The International Sources of Domestic Politics, 32 INT'L Org. 881 (1978); Robert O. Keohane, After Hegemony: Cooperation and Discord in the World Political Economy (1984); Robert D. Putnam, Diplomacy and Domestic Politics: The Logic of Two Level Games, 42 InT'L Org. 427 (1988); Robert O. Keohane, International Institutions and State Power: Essays in International Relations Theory (1989); Peter M. Haas, Introduction: Epistemic Communities and International Policy Coordination, 46 INT'L ORG. 1 (1992); Anne-Marie Slaughter, International Law and International Relations: A Dual Agenda, 87 AJIL 205 (1993); Andrew Moravcsik, Taking Preferences Seriously: A Liberal Theory of International Politics, 51 Int'L Org. 513 (1997); Helen V. Milner, Interests, Institutions, and Information: Domestic Politics and International Relations (1997); James G. March \& Johan P. Olsen, The Institutional Dynamics of International Political Orders, 52 InT'L Org. 943 (1998); Alexander Wendt, Social Theory of International Politics (1999); Oona A. Hathaway, Between Power 
Two important developments shaped the British strategy. On the one hand, powerful new antislavery voices - and especially anti-slave-trade voices-were influencing both public opinion and the government in the United Kingdom As Castlereagh himself explained regarding the abolition of the international slave trade, "[T] he nation is bent upon this object, I believe there is hardly a village that has not met and petitioned upon it; both Houses of Parliament are pledged to press it; and the Ministers must make it the basis of their policy."139 Indeed, the United Kingdom even recorded its opposition to the slave trade in the Treaty of Ghent itself: Article 10 of the treaty declared "the traffic in slaves" to be "irreconcilable with the principles of humanity and justice" and announced to the world that "both his Majesty and the United States . . . shall use their best endeavors to accomplish" its abolition. ${ }^{140}$

At the same time, Castlereagh's diplomatic goals with respect to the United States had shifted. The bitter disagreements that had led to war in 1812 were Napoleonic-era issues about shipping rights in the Atlantic and about the right to impress sailors on American vessels into the British navy. ${ }^{141}$ After the Treaty of Ghent, the primary problems on the AngloAmerican diplomatic agenda were the disputed boundary line between the United States and British Canada and the rights of New Englanders to fish in Canadian waters. ${ }^{142}$ AngloAmerican statecraft had turned to questions such as Spain's South American colonies-questions that would culminate in the announcement of the Monroe Doctrine in $1823 .{ }^{143}$ The slave compensation question paled in comparison.

Here, then, was Castlereagh's dilemma. An issue left over from a previous war was producing political controversy out of proportion with its diplomatic importance in the post-war world. The money was not a problem — the compensation that the United Kingdom eventually paid to the United States for the slaves who escaped to British lines amounted to less than one half of one percent of the country's expenditures for the year. ${ }^{144}$ The problem was

and Principle: An Integrated Theory of International Law, 72 U. CHI. L. Rev 469 (2005); Daniel Abebe, The Global Determinants of U.S. Foreign Affairs Law, 49 STAN. J. INT'L L. 1 (2013).

${ }^{139}$ Seymour Drescher, Whose Abolition? Popular Pressure and the Ending of the British Slave Trade, 143 PAST \& Present 136, 164 (1994). See also Jerome Reich, The Slave Trade at the Congress of Vienna: A Study in English Public Opinion, 53 J. Negro Hist. 129, 129 (1968) (explaining that "the campaign for universal abolition of the slave trade ... . was enjoined directly by organized and vocal public opinion" and that Lord Castlereagh and other leading British political figures " $[\mathrm{r}]$ epeatedly . . . testified to the popular pressure exerted on them and the absolute political necessity of satisfying it"). See supra notes 33-43 and accompanying text for a discussion of the British government's complicated relationship with slavery during this time.

${ }^{140}$ Treaty of Peace, supra note 47, at 748. See also Jenny S. Martinez, Antislavery Courts and the Dawn of International Human Rights Law, 117 YALE L.J. 550, 571-72 (2008).

${ }^{141}$ LATIMER, supra note 9, at 2, 25; HiCKEY, supra note 20, at 5-27.

${ }^{142}$ Perkins, supra note 1, at 122-24, 166-67, 244-45, 248-53, 263-67; Samuel Flagg Bemis, A Diplomatic History of the United States 173-75 (rev. ed. 1942); George C. Herring, From Colony to Superpower: U.S. Foreign Relations SinCE 1776, at 151 (2008). Indeed, the treaty that ultimately referred the runaway slave dispute to arbitration focused more on fisheries and the Canadian boundary than it did on the slave issue. Convention with Great Britain, supra note 82.

143 See Charles Bagot to Lord Castlereagh (Aug. 11, 1816), D3030/5034, Public Records Office of Northern Ireland (reporting his recent meeting with a revolutionary Mexican general); Charles Bagot to Lord Castlereagh (Jan. 7, 1817), D3030/5196 (describing the current relationship between the United States and Spain); Charles Bagot to Lord Castlereagh (Jan. 4, 1819), D3030/5679, Public Records Office of Northern Ireland (discussing the possibility of Great Britain and the United States "act[ing] in some concert . . . in regard to the revolutionary Provinces of South America”). See generally PERKINS, supra note 1, 296-302.

${ }^{144}$ The $\$ 1,204,960$ settlement that the two parties agreed to in 1826 equaled approximately $£ 270,000$, while the United Kingdom's gross public expenditures for that year amounted to $£ 54.1$ million. Mr. Gallatin to $\mathrm{Mr}$. Clay (Nov. 11, 1826), in 6 American State Papers: Foreign Relations, supra note 124, at 351, 352; B.R. 
how to resolve the dispute over the liberated slaves without losing credibility with antislavery constituencies in the British public and without conceding the legitimacy of post-war compensation claims made by a former colony that had started the war, burned Canadian towns, and then insulted British forces at New Orleans in a battle fought entirely after U.S. and UK officials at Ghent had already signed the treaty ending the war. ${ }^{145}$ In these circumstances, an arbitration process that would allow Castlereagh to blame a third party in the event of a loss must have held some appeal.

American statesmen experienced similar pressures toward arbitration. Once again there were domestic aplenty. The crucial American constituency was the slave owning class. Back in 1794, the Jay Treaty had abandoned southern slaveholders' claims to slaves carried off by the British after the War of Independence. White southerners had never forgiven John Jay for what they saw as his betrayal of their interests. ${ }^{146}$ Having been burned once in diplomatic negotiations, slaveholders were determined to obtain compensation for a new round of wartime losses. Yet American statesmen had relatively little power to insist on their interests in the dispute with the far-stronger United Kingdom, whose soldiers had marched through the U.S. capitol only a few years before. ${ }^{147}$

With these considerations in mind, the value of arbitration to both sides comes into view. Arbitration offered the British foreign office an opportunity to permanently resolve the dispute over escaped slaves so that its officials could focus on matters they regarded as more pressing. Arbitration also presented the British government with an opportunity to dispose of a dispute it no longer cared much about without risking its reputation as the global leader of the opposition to the international slave trade. Similarly, the neutrality and finality of arbitration offered Adams and Monroe political cover from the wrath of slaveholders in case of an unfavorable award. ${ }^{148}$ At the same time, arbitration offered the United States the possibility of receiving a favorable award that would bind their much stronger adversary in a way that mere diplomatic negotiations could not. ${ }^{149}$

Even if it made sense to arbitrate their dispute, however, why did the two countries pick the Russian emperor, of all people, to serve as arbitrator? As John Quincy Adams observed in his diary, "[T]here is something whimsical in the idea that the United States and Great Britain, both speaking English, should go to the Slavonian czar of Muscovy to find out their own meaning, in a sentence written by themselves, in the language common to them both." 150

Mitchell, British Historical Statistics 587 (1988). In contrast, the British government spent $£ 20$ million in compensation to slave owners after outlawing slavery in its empire in 1833. Julian Hoppit, Compulsion, Compensation and Property Rights in Britain, 1688-1833, 210 PAST \& Present 93, 118-19 (2011).

${ }^{145}$ LATIMER, supra note 9, at 30-34, 60, 132-33, 223-24, 381-88.

${ }^{146}$ WITT, supra note 2, at 72; FEHRENBACHER, supra note 2, at 92-93; OAKES, supra note 4, at 115-31; WALTER Stahr, John JaY: Founding Father 237-39 (2005).

${ }^{147}$ LATIMER, supra note 9, at 315-22.

${ }^{148}$ Cf. Loretta Malintoppi, Methods of Dispute Resolution in Inter-state Litigation: When States Go to Arbitration Rather than Adjudication, 5 Law \& PraC. INT'L CTS. \& Tribunals 133, 133 (2006) (arguing that "negotiating issues of considerable domestic sensitivity" might at times prove impossible, and observing that in such cases "[s] tates may find it preferable to submit such disputes to a panel of neutral judges in order to avoid making unpopular decisions and 'lose face' before their public opinion." Noting further that any criticism of such a decision might "conveniently fall on the arbitral panel or the judicial body and not the relevant government").

${ }^{149}$ J.G. Merrills, International Dispute Settlement 111 (5th ed. 2011) (explaining that arbitration allows states achieve "a decision which is binding").

${ }^{150}$ ADAMS, supra note 50, at 160. 
In fact, selection of the czar as arbitrator fit perfectly with the larger political goals of each side. The United States could confidently expect the British to adhere to the decision of a powerful and well-respected sovereign if the czar's award favored the American claimants, especially because the British had an important stake in their relationship with Russia. ${ }^{151}$ Thus, the United States could count on the czar's ruling to serve the binding function of international arbitration. In addition to their strong legal case, American diplomats might have hoped that the czar would favor their comparatively weak country over his old adversary Great Britain in order to maintain the global balance of power. ${ }^{152}$ And perhaps the United States would even benefit from the friendly relationship that Adams had developed with Alexander years earlier while serving as the American Minister to Russia. ${ }^{153}$

The British government also had good reason to select the czar as arbitrator. British diplomats and leading antislavery figures in the United Kingdom had been engaged in a campaign to persuade Alexander to join them in opposition to the slave trade since before the commencement of the Treaty of Ghent dispute, and by 1818 they thought they were succeeding. ${ }^{154}$ Thus, the British believed that the emperor would prove sympathetic to their antislavery position when making his decision. At a minimum, his selection as arbitrator offered further assurance to domestic constituencies that the Foreign Office had done its best to advance anti-slave-trade values.

In short, then, arbitration by the czar offered both the United Kingdom and the United States a solution to a tricky and complex problem of cross-cutting international interests and domestic politics. Third-party dispute resolution helped smooth domestic political controversies while facilitating the pursuit of important foreign policy projects.

In view of the good reasons both sides had to arbitrate their dispute, the solution to the puzzle of who won the czar's decision may actually not be so clear. Formally, the czar awarded a win to the United States. But in important respects, the British won, too. In return for what was ultimately a relatively small sum in damages, British diplomats managed to hold off payment of compensation for more than a decade. Castlereagh's suicide in 1822 meant that he never got to see the dénouement of the affair, yet arbitration allowed the British to address the new boundary and fisheries questions that he and Bagot rightly understood as more pressing

151 See John Quincy Adams to Thomas Boylston Adams (Feb. 14, 1810), in 3 WRitings of John QUincY ADAMs, supra note 27, at 397, 398 (declaring that "Emperor Alexander . . . is a character highly distinguished among the sovereigns of the world" and describing him as "a powerful and absolute prince" whose "spirit of benevolence and humanity is ... universally recognized").

${ }^{152}$ Farsolas, supra note 90, at 32. After the rise of the Russian Empire under Peter the Great in the early eighteenth century, diplomatic relations between Britain and Russia "oscillate[d] between friendliness and hostility." A. Lobanov-Rostovsky, Anglo-Russian Relations Through the Centuries, 7 Russian Rev. 41, 43 (1948). Indeed, the two countries were formally at war with each other from 1807-1812, though no real hostilities occurred, and in 1815 they fought together to defeat Napoleon Bonaparte at Waterloo. Id. at 45. After the end of the Napoleonic Wars, the two empires began competing with each other in Asia. Id. at 46; see generally GERALD MORGAN, ANGLORussian Rivalry in Central Asia, 1810-1895 (1981).

${ }^{153}$ LEVIN, supra note 26, at 437, 446-47.

${ }^{154}$ See Thomas Clarkson to Lord Castlereagh (c. Oct. 1818), D/3030/5638, Public Records Office of Northern Ireland (describing his interview with the Tsar on the slave trade); Lord Castlereagh to Lord Stewart (Nov. 29, 1818), D/3030/5667, Public Records Office of Northern Ireland (describing proceedings at Aix, his interview with the Tsar, and his recent conversation with Metternich); Thomas Clarkson to [Alexander I], Emperor of Russia, and Robert Stewart, Viscount Castlereagh (Sept. 30-Oct. 5, 1818), CN59, Huntington Library, San Merino, California; Thomas Clarkson, Interview with [Alexander I,] Emperor of Russia (Oct. 9, 1818), CN 60, Huntington Library. 
to British interests of the day. Moreover, the confusion attendant on the czar's decision allowed the United Kingdom and the United States each to claim victory, at least for a time. In a formal sense, the United States won. Officially, the czar had handed American statesmen a victory. In important respects, however, it was awfully hard to say who gained more from referring the slave dispute to the czar. American statesmen were not the only ones with reason to be pleased with the arbitration process. And therein lay some of the genius of the czar's arbitral decision.

It is hard to know what one further constituency may have thought about the czar's decision. The arbitration may also have mattered to the refugees from slavery who had occasioned it by leaving their owners' plantations and taking shelter behind British lines. Freedom was fragile at the periphery of early nineteenth-century European empires. Thousands of persons freed in Haiti during the French Revolution had been re-enslaved when political winds changed in Paris and Napoleon turned against freedom. ${ }^{155}$ Those who had escaped from the Chesapeake or along the Gulf Coast may have feared that their new freedom was in the balance, too. In the early days after the Treaty of Ghent, American slaveowners had demanded the return of the formerly enslaved persons themselves. As time went on, American claims for the return of slaves inevitably became claims for cash compensation. Delay worked in the refugees' favor. The freedom they gained was no utopia, however. Some of the 5,000 courageous men and women who had escaped to British lines during the war settled in Trinidad. A plurality ended up in Nova Scotia. In both places, discrimination and hardscrabble agriculture made for challenging lives. Nonetheless, in a controversy that bounced around the Euro-American world, from the Chesapeake to London, from Washington to St. Petersburg, and from the Caribbean to the British maritime provinces of eastern Canada, 5,000 enslaved people had done what they could to forge their own destinies. ${ }^{156}$

\section{Conclusion: A Second Puzzle}

The story of the War of 1812 refugees connects to a second and broader puzzle, too, one that stretches well beyond the question of who won the dispute over their escape. The second puzzle is to make sense of the relationship between international law and slavery in the nineteenth century.

The story of the czar and the slaves sits uneasily alongside an increasingly prominent theme in the literature on the history of international law. In this literature, modern international law and the antislavery movement emerged together. Dean Jenny Martinez's widely discussed scholarship advances one version of this view, focusing on the international treaty courts established by the United Kingdom and other states beginning in 1817 to adjudicate the status of slave trading vessels and to enforce domestic prohibitions on the slave trade. The

155 See generally Rebecca J. Scott, Paper Thin: Freedom and Re-enslavement in the Diaspora of the Haitian Revolution, 29 Law \& Hist. Rev 1061 (2011); Graham T. Nessler, "They Always Knew Her to be Free": Emancipation and Re-enslavement in French Santo Domingo, 1804-1809, 33 SLAVERY \& AbOLITION 87 (2012).

${ }^{156}$ Robin W. Winks, The Blacks in Canada: A History 114-41 (2d ed. 1997); Harvey Amani Whitfield, Blacks on the Border: The Black Refugees in British North America, 1815-1860 (2006); Harvey Amani Whitfield, The Development of Black Refugee Identity in Nova Scotia, 1813-1850, 10 Left History 9 (2005). See also RICHARDSON, supra note 2, at 437 (describing the agency of enslaved people in the War of 1812 disputes over slavery). 
campaign against the slave trade, Martinez has contended, anticipated later human rights movements. ${ }^{157}$ A second version of the literature on slavery and international law, championed recently by Lauren Benton and Lisa Ford, holds that opposition to the slave trade and to some of the brutalities of slavery was not a forerunner of human rights but a tool for building and legitimating the capacity of powerful European empires, especially the British Empire. ${ }^{158}$

Either way, to be sure, debate continues about how effective international law mechanisms were against the slave trade. On the one hand, the anti-slave-trade institutions of the British Empire rescued many tens of thousands of enslaved people; the mixed commissions alone freed 80,000 people held as slaves. ${ }^{159}$ On the other hand, the slave trade continued to thrive despite the slave trade treaties, the British navy, and the mixed commissions. As many as one quarter of all the slaves crossing the Atlantic in more than three centuries of Atlantic slaverysome three million souls out of twelve million total — made the journey after the United Kingdom and the United States had criminalized the trans-Atlantic traffic in people. ${ }^{160}$ Moreover, the fate of slaves who were rescued by institutions such as the mixed commissions remained uncertain and often grim. Few were able to return to their homes; many were forced into indentures or apprenticeships resembling slavery; some were recaptured back into the trans-Atlantic slave trade. ${ }^{161}$

The czar's arbitration in 1822 further illuminates the already complex relationship between slavery and the emerging institutions of modern international law. In particular, American victory in the czar's arbitration offers further evidence that in precisely the same years in which the British were assembling treaties and courts to oppose the slave trade, other pieces of new the new international legal order were actively supporting the institution of slavery. The czar's arbitration award is hardly the only such evidence, to be sure. One unintended effect of the British legal efforts against the slave trade was to reveal the deep support for slavery and the slave trade afforded by basic international law principles. Core rules of international law such as the equality of sovereign states and the immunity of foreign vessels from search in peacetime constrained the British navy, along with its admiralty courts and its treaty courts, from taking more aggressive steps in policing the trans-Atlantic slave trade. ${ }^{162}$

\footnotetext{
${ }^{157}$ Martinez, Slave Trade, supra note 5, at 6, 13 (“[T] he nineteenth-century slavery abolition movement was the first successful international human rights campaign, and international treaties and courts were its central features."). Eugene Kontorovich observes importantly that the United States declined to enter into a bilateral slave trade treaty with the British, in part because of constitutional limits on non-Article III courts. See Eugene Kontorovich, The Constitutionality of International Courts: The Forgotten Precedent of Slave-Trade Tribunals, 158 U. Penn. L. Rev. 39 (2009).

${ }^{158}$ BentON \& Ford, RAGE FOR ORder, supra note 5; Benton, Abolition and Imperial Law, supra note 5; Benton, This Melancholy Labyrinth, supra note 7.

${ }^{159}$ Leslie Bethell, The Mixed Commissions for the Suppression of the Transatlantic Slave Trade in the Nineteenth Century, 7 J. African Hist. 79, 79 (1966) (80,000); see also Martinez, The Slave Trade, supra note 5, at 11.

${ }^{160}$ David Eltis, Was Abolition of the U.S. and British Slave Trade Significant in the Broader Atlantic Context?, 66 WM. \& MARY Q. 715, 722 (2009); Richard Murphy, The Limits of Law: British Efforts to Suppress the Slave Trade, 1818-1850 (Spring 2014) (unpublished B.A. thesis, University of Colorado), available at https://scholar. colorado.edu/honr_theses/171.

${ }^{161}$ Rendall Lesaffer, Mixed Commissions, Mixed Blessings: On the British-Portuguese Anti-Slave Trade Treaty of 1817, in Oxford Public International Law (2019), available at http://opil.ouplaw.com/page/mixed-blessing. See also Jake Christopher Richards, Anti-Slave-Trade Law, "Liberated Africans" and the State in the South Atlantic World, 1839-1852, 241 PAST \& PRESENT 179 (2018); Suzanne Schwarz, Reconstructing the Life Histories of Liberated Africans: Sierra Leone in the Early Nineteenth Century, 39 Hist. AfriCa 175, 201-03 (2012).

${ }^{162}$ E.g., Helfman, Vice Admiralty, supra note 5, at 1148-52.
} 
New literature on the laws of armed conflict and on the principle of necessity also shows that the United States in particular used international law to promote distinctly pro-slavery arguments right up into the American Civil War. ${ }^{163}$

The victory of American slaveholders in the St. Petersburg arbitration adds another proslavery dimension to the story of nineteenth-century international law. John Quincy Adams had contended that the Treaty of Ghent's slave provisions should be interpreted in accordance with what he insisted were the proper background principles of the laws of armed conflict on slavery. Belligerents cannot, he asserted, capture or liberate enemy slaves in wartime, which were, he had said, "entitled, by the laws of war, to exemption from capture."164 The United States had supported this position since at least 1775, when the last royal governor of Virginia had promised freedom to any slaves escaping to British lines in the War of Independence. Of course, the czar's resolution of the treaty dispute technically confined itself to the terms of the Treaty of Ghent. The decision did not necessarily imply approval of Adams's dictum on behalf of slavery in international law. But at the end of the day, a basic truth remained. American slaveowners had won an international arbitration over the liberating forces of the British army and navy. International legal institutions, it seemed, could support slavery just as effectively as they undermined it, if not more so.

The czar's arbitration was a win for the United States and an acceptable loss for the United Kingdom. For the emerging institutions of international law, it offered evidence at the founding moment of Britain's bilateral anti-slave-trade treaty courts that the tools of the law could be deployed to very different ends. International law, it seemed, was neither pro-slavery nor anti-slavery. Instead, it was an increasingly prominent forum for the contest over slavery in the nineteenth-century Atlantic world.

${ }^{163}$ WITT, supra note 2; John Fabian Witt, A Lost Theory of American Emergency Constitutionalism, 36 LAW \& Hist. Rev. 551 (2018).

${ }^{164}$ For the Adams quotation, see supra text accompanying note 69. 